Reprod. Nutr. Dévelop., 1986, 26 (4), 877-920.

\title{
Spermatogenesis and spermatology of some teleost fish species ( $\left.{ }^{1}\right)$
}

\author{
R. BILLARD ( $\left.{ }^{2}\right)$
}

Station de Physiologie animale, I.N.R.A., 78350 Jouy-en-Josas, France.

Summary. In teleost fish, the whole of the processes involved in the formation of spermatozoa and their release and in fecundation are extremely diverse.

Two main types of testicular structure are distinguished : a tubular and a lobular. The organization of the lobules and genital duct structure is very diverse in the latter type.

Spermatogenesis can be continuous, as in guppy, discontinuous with overlapping cycles, as in carp, or show well separated cycles as in trout.

Spermiogenesis shows increasing degrees of complexity, leading to the formation of extremely simple spermatozoa as in carp (spherical head, very little nuclear histone transformation, very simple mid-piece with untransformed cytoplasmic and mitochondrial remains) or much more complex spermatozoa as those of guppy (elongated head, histoneprotamine transformation, transformation of the centriolar complex in the deep nuclear notch, very developed mid-piece with glycogen stores).

Spermatogenetic production is extremely variable (GSI: $0.1-10 \%$; annual production : $1.10^{8}$ to $7.10^{9}$ spermatozoa/g body weight).

Spermiation yield varies according to species but also within the same species $(20-90 \%$ in trout).

The endocrine model of spermatogenesis and spermiation is very different in carp and trout. The main environmental factor influencing spermatogenesis is photoperiod in trout and temperature in carp; spermiation depends on temperature in trout and on social environment as well as temperature in carp.

Sperm physiology (survival time in vivo and in vitro, motility time, metabolism) is very different in the several species studied. Two groups with a fundamentally different physiology (internal or external fecundation), sperm biology and morphology (structure of testis and spermatozoon) can be grossly distinguished. These groups are fish with lobular testes (guppy) and those with tubular testes (teleosts).

\section{Introduction.}

The reproductive function in male teleosts is original in several ways.

1. There is a wide variation in the amount of spermatozoa produced. This is indicated by the increase in testicular weight at the same time as body weight

(1) This paper reviews the personal work of the author and co-workers; their articles are noted in parenthesis in the text and given in a list at the end.

$\left.{ }^{2}\right)$ Present address : Museum national d'Histoire naturelle, Ichtyologie, 43, rue Cuvier 75231 Paris. 
(fish growth is a continuous or subcontinuous process); testicular weight is usually expressed as a percentage of empty body weight or as gonadosomatic index (GSI). In annually reproducing species this gonad growth reaches 5 to $10 \%$ in salmonids (Hiroi and Yamamoto, 1968, 1970) and cyprinids (Solewski, 1957 ; Weil, 1981), 2 to $3 \%$ in pike (Medford and Mackay, 1978) and 0.2 to $2 \%$ in various tilapia (Peters, 1971). Spermatogenetic production has been studied in detail in only a small number of cases (Turdakov, 1968), but since spermatozoa constitute the majority of cells in the mature testis, testicular weight is thought to be a good criterion of the quantity of spermatozoa produced. It is therefore evident that spermatogenetic activity varies greatly from one species to another. The reasons for these differences are not clear and they have been little discussed by authors, even in recent reviews on spermatogenesis (Nagahama, 1983). Other than aspects of quantitative production, it is necessary to consider sperm quality and the true amounts of spermatozoa available for fertilization.

2. The periods during which spermatogenesis occurs differ widely as well as the time at which the gametes are released (review by Billard and Breton, 1978). It is supposed that spermatogenesis is continuous in male guppies in the laboratory because females seem to be gravid all year long (Rosenthal, 1952 ; Billard, 1966). In nature, spermatogenesis is seasonal in temperate zone species ; Atlantic salmon (Jones and Orton, 1940), brook trout (Henderson, 1962) and pike (Lofts and Marshall, 1957) show spermatogenesis in summer and the sea-bream in spring (Papadopol, 1962). In some cases, spermatogenesis may begin in autumn and finish in spring as in the stickleback (Craig-Bennett, 1931) ; it appears to also be seasonal in some subtropical and tropical species (Barbus liberiensis : Payne, 1975 ; tilapia : Hyder, 1970; see review by Lam, 1983). Sperm release or spermiation also takes place at very different seasons (autumn and winter in salmonids and spring or summer in cyprinids) ; it coincides with the rainy season in the tropics. In temperate zone species, it is interesting that spermiation and spawning occur at such different seasons although conditions favoring maximal juvenile survival, such as availability of food that is sufficient in quality (prey size corresponding to larval mouth size) as well as quantity, only occur in spring or summer.

3. The modes of reproduction are very diverse. This question has been reviewed in detail by Breder and Rosen (1966). Some species are viviparous and have internal fecundation, while other more numerous species present external fecundation in very diverse media (fresh water, salt water, briny water) where the gametes are subjected to considerable osmotic shock. Laying and incubation substrates (grass, algae, gravel) also vary. The male sometimes incubates the eggs. Reproductive behavior is very diversified; some species spawn in couples, while others spawn in groups. This variety of reproductive modes is often associated with important body changes (permanent or temporary) or with endocrine adaptation directly related with the reproductive function. The hippo-

Abbreviations : GA : type A spermatogonia ; GB : type 8 spermatogonia ; $\mathrm{GSI}$ : gonadosomatic index: $P G C$ : primary germ cell 
campus male, which incubates the eggs, presents changes in tegument due to specific endocrine determinism (Boisseau, 1967). These general observations, usually based on field work, seldom contain any detailed analysis of the dynamics of spermatogenesis or spermiation or of the quantity and biology of the spermatozoa involved in reproduction.

The present work uses several freshwater species of the temperate zone, such as salmonids and cyprinids, as examples and describes and quantifies the formation, release, morphology and viability of their spermatozoa. These species will be compared with the guppy, a tropical species which reproduces continually. Spermatogenesis, its endocrine regulation and sperm biology will be analysed using some examples to illustrate widely diverse modes of reproduction. We shall also define the positive and negative environmental factors that determine the times of the year at which spermatogenesis and spermiation occur in the species studied. The literature on spermatogenesis in teleost fish will not be exhaustively reviewed here; readers are referred to several recent reviews on this subject which summarize the state of the art (Grier et al., 1980 ; Grier, 1981 ; Bruslé, 1982 ; Nagahama, 1983 ; Fostier et al., 1983 ; Stoss, 1983 ; Van Thienoven, 1983).

The aim is to better understand the regulatory mechanisms initiating seasonal reproduction and the emergence of juveniles at the same time that qualitatively and quantitatively suitable food supplies become available in the environment.

\section{The morphological and dynamic aspects of spermatogenesis}

\subsection{Testis morphology.}

The morphology of the testis has been studied macroscopically (1) and microscopically (2). The testis is usually paired but the two lobes may be partially fused, as in perch, or totally fused, as in guppy. Two types of testicular structure are distinguished.

1.1.1. Tubular type (guppy) (1). - At the center of the testis is a large cavity (fig. 1) where the spermatozoa are stored; they are grouped into bundles called

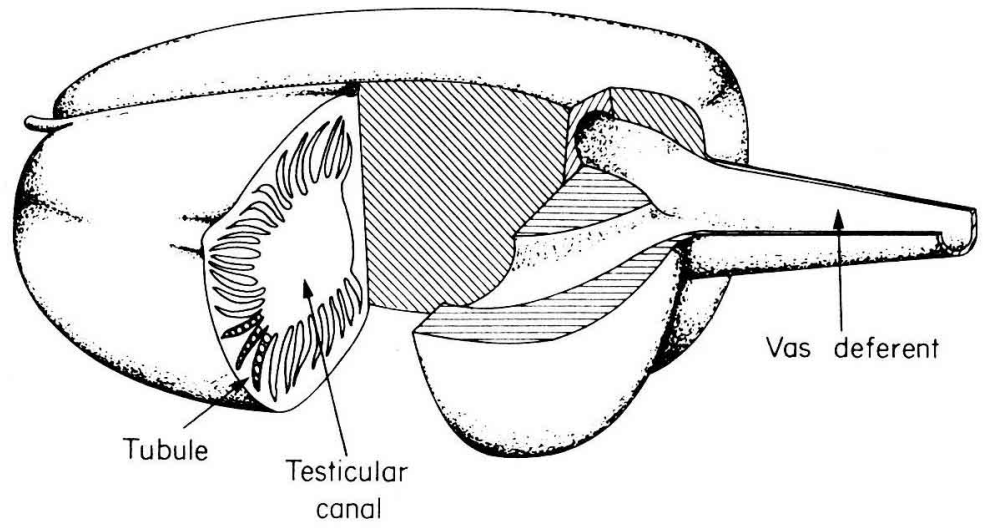

FIG. 1. - Structure of the testis of the guppy (Poecilia reticulata). 
spermatozeugmas. Tubules radiate from this cavity towards the periphery (fig. 2); the blind end (apex) of these tubules is apposed against the testicular capsule. Isolated germ cells (3), the stem spermatogonia, are found concentrated at the apex. Immediately below the germ cells, the B spermatogonia organize into cysts which progress towards the center of the testis during spermatogenesis (fig. 2) (4).

1.1.2. Lobular type. - In this type, connective tissue extends from the testicular capsule to form irregular " tubes" lined with a Sertoli cell epithelium including germ cells (fig. 3). The blind end is apposed against the testicular capsule ; the tubes converge ventrally towards a sperm collection system. Lobular structure is thus different from tubular structure; type $A$ spermatogonia (GA's) are found all along the lobule, while in the tubule they are localized in the apex. During spermatogenesis, the cysts move only slightly towards the center of the lobule; the spermatozoa are released into the lobule lumen from which they reach the efferent and deferent systems (fig. 2) $(4,5)$. The complexity of lobular testis structure varies with the species since the extensions of connective tissue may overlap more or less.

1.1.3. Interstitial cells and the interlobular space. - The lamina of connective tissue from the capsule is composed of fibroblasts bordered on the lobule side by a basal lamina against which Sertoli cells are apposed. The

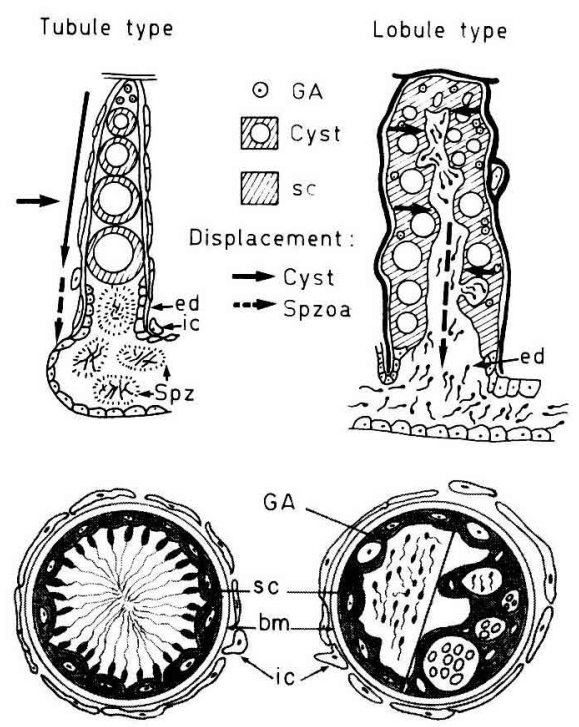

FIG. 2. -- Schematic illustration of the two types of teleost testicular structure tubular and lobular. Tubular type (guppy): Top left : A spermatozoa (GA's) are found only in the apex of the tubule and cysts are migrating towards the efferent duct (ed). Bottom left : cross-section of a spermatid cyst.

Lobular type (trout): Top right: GA's and cysts are seen throughout the length of the lobule spermatozoa are released into a central lumen. Bottom right : cross-section of a lobule. Left : sexual rest. Right : spermatogenetic activity.

ic : interstitial cell ; bm : basal membrane ; sc : Sertoli cell. 
fibroblasts form a quasi-continuous layer around the tubules and a discontinuous one around the lobules (fig. 2). Using morphological criteria, interstitial cells can be distinguished between the fibroblast layers. They are found in all studied species such as guppy, trout, pike, goldfish, roach, carp and tilapia (6).

1.1.4. Genital tract. - The male genital tract is very simplified in guppy; a single duct, equivalent to a vas deferens, connects the central lumen of the testis with a genital papilla (1) (fig. 4).

At the place where the open ends of the lobules converge in other teleosts with lobular testes, there is an epithelial area which has no germ cells and delimits a space where the spermatozoa accumulate. This area, found all along the testis, is connected at its posterior part to a duct that joins it to the genital papilla. The two original ducts in both testes fuse at the genital papilla. The whole of this collection system, intratesticular and extratesticular, acts as a spermiduct. The structure of the epithelium lining the extratesticular part varies according to the species and the sex cycle stage. In trout, the epithelium is secretory and may phagocytose the spermatozoa (7) and the spermiduct is long (as long as the testis itself) and distends to become a true sperm storage organ, attaining a space of $10 \%$ of the body weight. On the contrary, in carp the length of the free

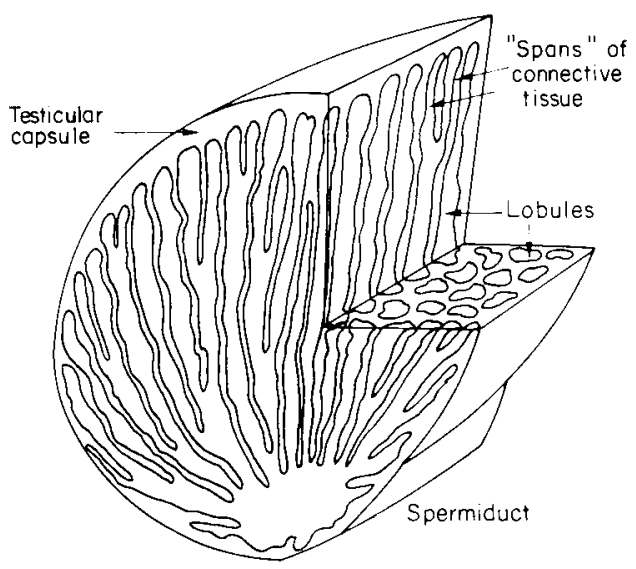

FIG. 3. - Schematic illustration of trout testicular structure (/obular type). The lobules are delimited by connective extensions from the testicular capsule.

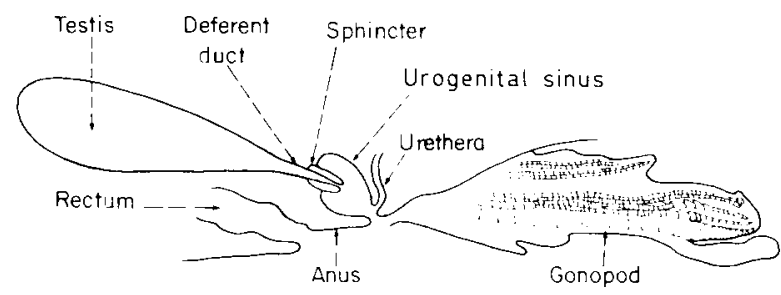

FIG. 4. - Schematic illustration of the adu/t Poecilia reticulata genital tract. 
spermiduct is very reduced and in no case is it a large storage organ. No accessory gland, except for a small diverticulum at the base of the spermiduct in pike, can be microscopically identified in the species studied; the function of this diverticulum is unknown. The spermiduct in trout contracts spontaneously, the amplitude of the contractions decreasing with the temperature (4). These contractions do not occur in the testis itself.

\subsection{Morphology of Sertoli cells and germ cells.}

1.2.1. Sertoli cells. - In the guppy (8) as in other teleosts with lobular testes (5), germ cells other than spermatozoa, whether isolated or in groups, are surrounded by Sertoli cells; the germ cells are never in contact with the basal lamina. Several roles, based on morphological criteria, have been attributed to the Sertoli cells: (i) the support and structuration of lobules, tubules and cysts; (ii) the spermatozeugma morphogenesis in guppy; (iii) the transfer and eventual conversion of metabolites or hormones towards germ cells or the central cavity ; (iv) the phagocytosis of germ cells and residual spermatozoa. The Sertoli cells seem to be permanent in lobular testes but degenerate in the guppy, and we have no clear understanding of their renewal or origin; (v) the isolation of the cyst compartment beyond the spermatocyte stage due to the appearance of tight junctions which prevent peroxidase penetration (Marcaillou and Szöllösi, 1980).

\subsubsection{Primordial germ cells (PGC) and spermatogonia.}

Tubular testis. - Several large GA's found in the guppy apex have nuclei measuring between 8 and $10 \mu \mathrm{m}$ in histological preparations. These nuclei have only one rather large, more or less central nucleolus and several chromatin filaments that radiate towards the periphery (1). These cells are interpreted as type A (GA) spermatogonia. Ultrastructural analysis (3) shows that each one is almost entirely surrounded by a layer of Sertoli cytoplasm. They have few structured organelles, only a few mitochondria and little reticulum (3). The presence of PGC in adult guppy was not cleared.

Lobular testis. - Some germ cells in trout similar to those in guppy are inserted in the Sertoli layer all along the lobules. They are more numerous in the lobular than in the tubular apex. The morphology seen in photonic microscopy of the nucleus $(10 \mu \mathrm{m})$ of embryonic gonad cells in newly-hatched alevins is similar and the cells are considered to be primordial germ cells (PGC). Their total number is about 50 (9). They show mitotic activity and yield two types of gonocytes which are morphologically different in photonic microscopy (9) and least one of which (G2) may occur in adult males.

Spermatogonia grouped in cysts appear to be irreversibly engaged in spermatogenesis and are interpreted as type B spermatogonia (GB). By estimating the number of cells in various types of cysts, it has been determined that there are 14 spermatogonial generations in guppy. During these generations, cell diameter decreases from 7 to $3 \mu \mathrm{m}$ (measured on histological sections) and the chromatin becomes more dense (1) as the organelles diversify (3) (8).

The cysts of species with lobular testes cannot be dissected and they are therefore difficult to identify in seriated sections; this makes it impossible to 
routinely count the cells they contain and thus the number of spermatogonial generations.

There appears to be fewer spermatocytes per cyst in trout than in guppy, suggesting a reduced number of spermatogonial generations.

1.2.3. Spermatocytes. - Guppy spermatocytes have been thoroughly analysed (1-3). Leptotene spermatocytes are distinguished from final spermatogonia by their larger nuclei $(4 \mu \mathrm{m})$. The cysts increase in size. Changes in the various leptotene-zygotene and pachytene phases occur synchronously in each cyst and all the cells of a cyst seem to be linked by cytoplasmic junctions. There are few spermatocyte $1 /$ cysts, indicating that this phase is short. Spermatocyte morphology is similar in species with lobular testes.

1.2.4. Spermatids. - Spermatid morphology, spermiogenetic profile and final sperm structure show diverse degrees of complexity depending on the species (fig. 5). The most complex type, occurring in guppy (10), shows an extremely developed mid-piece formed during spermiogenesis at the same time that the nuclear head elongates along with the microtubular structures. During elongation, dense chromatin elements appear in the nuclear periphery which correspond with the appearance of protamine in the nuclear proteins (11). Glycogen particles are visible in the mid-piece (12).

In trout, the nucleus elongates slightly as the chromatin becomes more dense (13). The centriolar complex changes little (14) and the mid-piece is reduced to a ring-shaped mitochondrion (13-15). A septum appears in the $A$ microtubule of some doublets (16). The spermatozoon head shows symmetric revolution. Spermiogenesis in carp and pike is very brief ; the sperm head generally remains spherical with the flagellum inserted on one side of the sphere by an unmodified centriolar complex. The mid-piece is reduced (14). An original type of spermiogenesis has been described in the eel (17) where the nucleus elongates greatly and a mitochondrion is found in the anterior part of the sperm head.

In conclusion, fish spermatozoa, even when very complicated as in guppy, are primitive compared with those of higher vertebrates; the chromatin is less transformed and condensed and the mid-piece is very reduced.

\subsection{Dynamics of spermatogenesis.}

1.3.1. Spermatogenetic cycle. - An examination of the guppy testes shows that there is continuous spermatogenetic activity throughout the year ; spermatozeugmas can be collected all year long (Billard, 1966) without modifying the reserves, showing that production is permanent. This is not true in species with lobular testes where spermatogenesis is not continuous. Two main types of spermatogenetic cycles have been distinguished.

- In trout there are two successive, distinct cycles. All the spermatozoa of one cycle are eliminated before the next cycle begins; only the GA's are permanent (fig. 6-7) $(24,25)$. The situation is similar in roach (fig. 7) (26), tench (27) and pike (28-32).

- In carp the two successive cycles are not as distinct. GB's and spermatozoa are always present in the lobules as well as GA's. Spermatozoa and spermatids, 


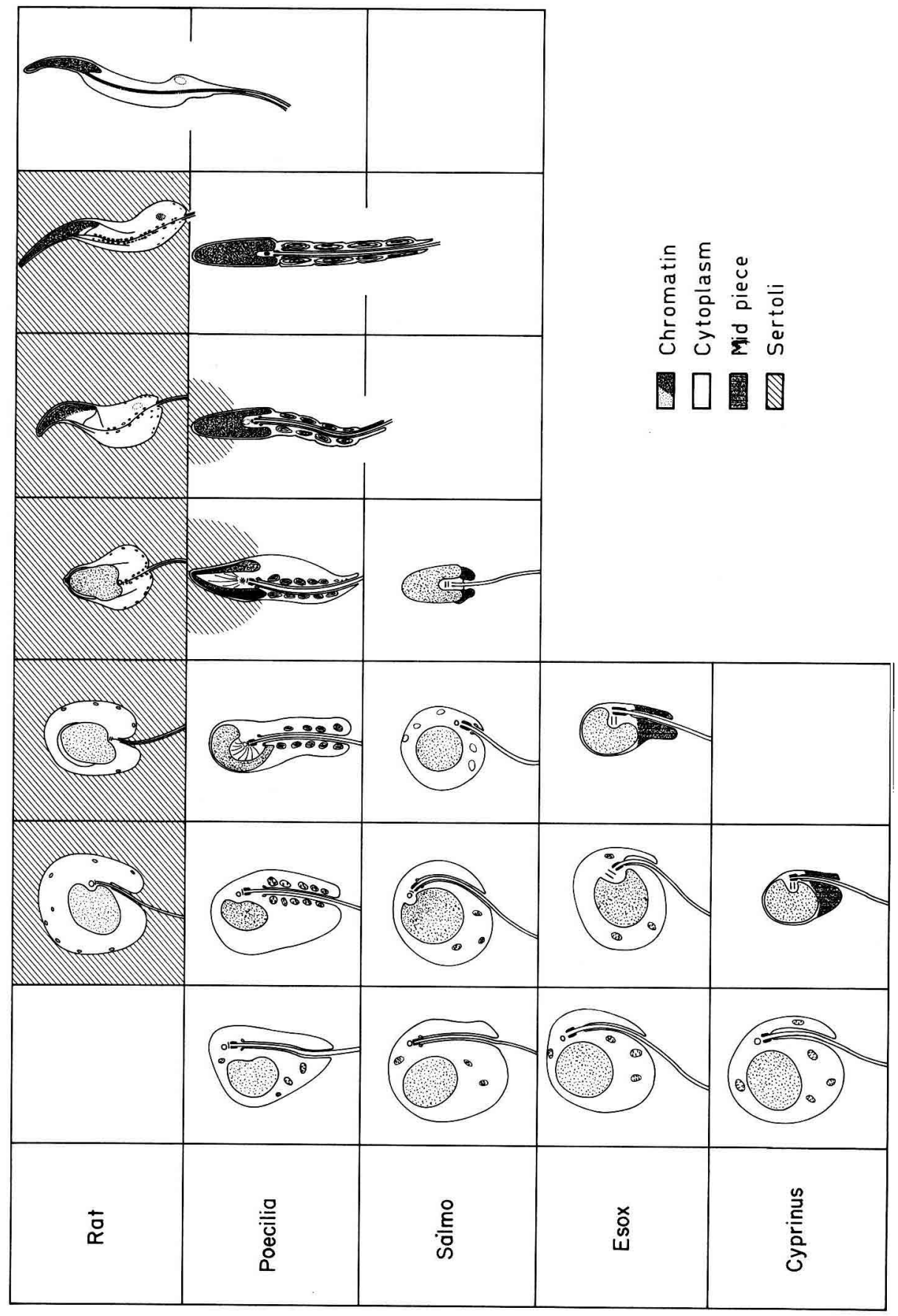

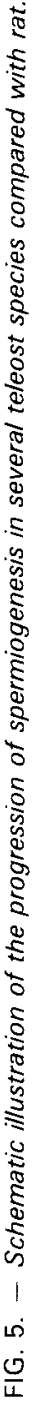




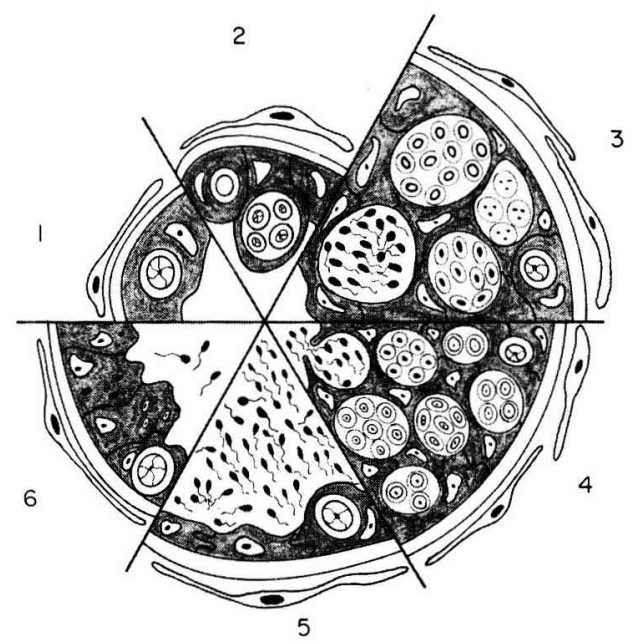

FIG. 6. - Schematic illustration of the spermatogenetic cycle in a rainbow trout lobule.

1. Inactive spermatogenesis: 2 . primary spermatogonium multiplication: 3 . active spermatogenesis; lobular size increases considerably; 4. active spermatogenesis; release of early spermatozoa ; 5 . spermiation ; 6 . spermatozoa are eliminated by release or resorption.

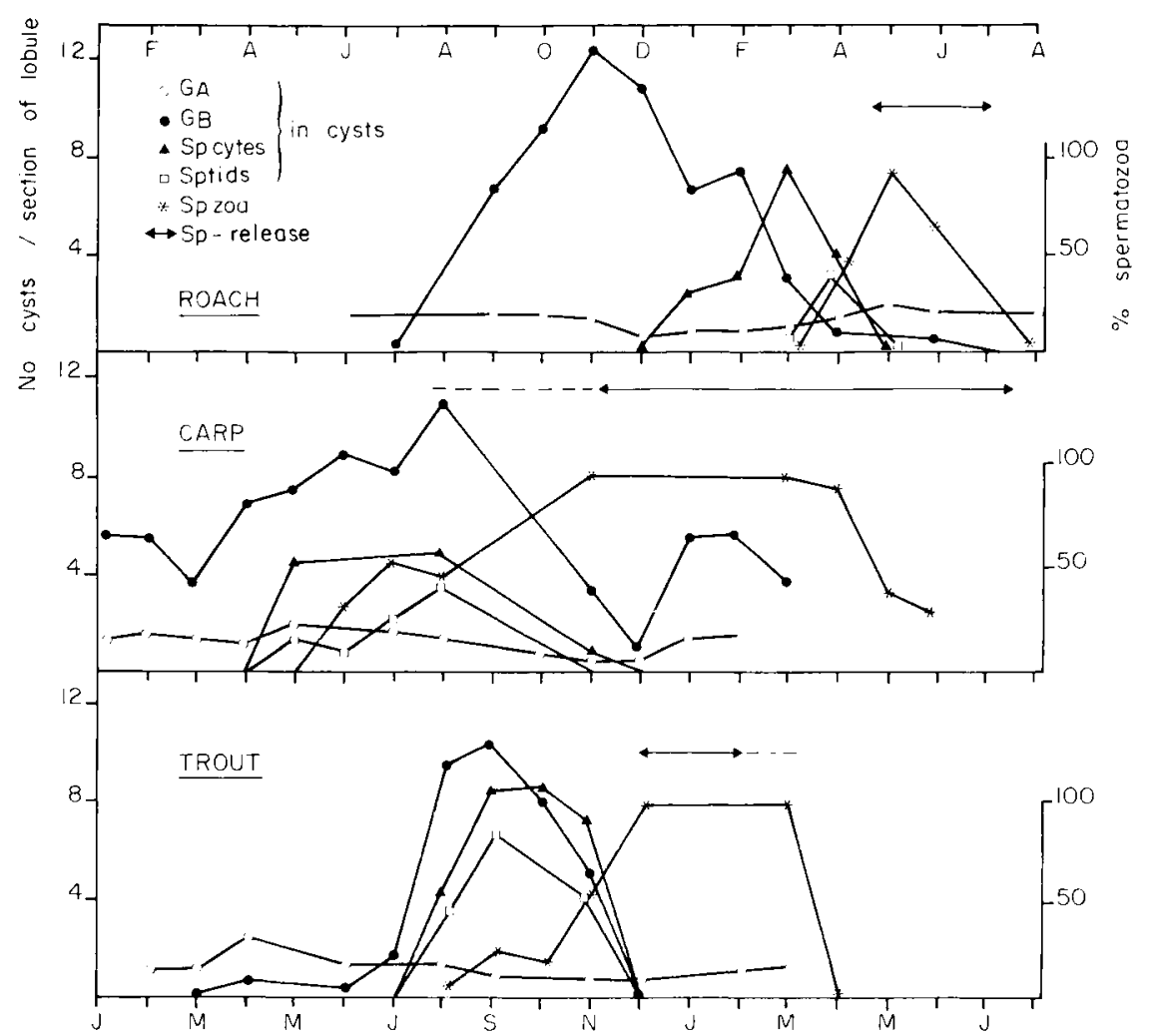

FIG. 7. - Evolution of various cell types (number of cysts per orthogonal section of lobule) during the annual reproductive cycle in roach, carp and trout. 
found in summer, correspond to the main spermatogenetic activity which is accompanied by a rise in the GSI (fig. 7) (25).

The histological images of these two types of spermatogenesis are very different. Well-defined phases succeed each other in trout : spermatogenesis and the presence of cysts, GA's + spermatozoa, GA's alone. In carp, cysts and spermatozoa occur permanently (22).

The period when active spermatogenesis occurs varies with the species. In carp and trout it takes place in summer and in tench in spring; in roach it begins in autumn and finishes in spring. The different types of spermatogenetic cycle can thus be identified by the season at which they occur (fig. 8) (29). Spermatogenesis lasts 36 days at $25{ }^{\circ} \mathrm{C}(1)$ in guppy and the leptotene-spermiation interval 14 days (18). In roach, the latter interval lasts 30 days at $10^{\circ} \mathrm{C}$ (Gillet and Billard, unpublished).

1.3.2. Spermatogenetic production. - The guppy produces an average of 36 spermatozeugmas per day (19) or 750000 spermatozoa daily, counting the number of spermatozoa per spermatozeugma (1). The values obtained for several species with lobular testes are given in table 1.

1.3.3. Spermiation. - The term "spermiation » in guppy means the same as in mammals, i.e. the detachment of spermatozoa from the Sertoli cells. In lobular testes, this term has no morphological basis since the spermatids are not inserted in the Sertoli cell layer. The term "spermiation " could correspond to the opening of the cysts and the release of spermatozoa into the lobule lumen, but it is the usage to refer to the release of spermatozoa by the testis and their arrival in the spermiduct. The expulsion of spermatozoa from the spermiducts (sperm release) by abdominal massage shows that the process exists ; its intensity is estimated by measuring sperm volume after massage, the sperm being collected in a test-tube placed under the abdominal pore. In this way, most of the sperm in the spermiducts can be collected. The volume of milt and sperm concentration, estimated by spermatocrit (32) and optic density (33), are measured during the reproductive period in trout $(30,31)$ and pike $(32)$.

In both species, the total number of spermatozoa collected is much lower than spermatogenetic production (table 1). No systematic study has been done in carp, but regular measurements at given times have shown that sperm volume is low when there is no hormonal stimulation (see below). In species such as trout

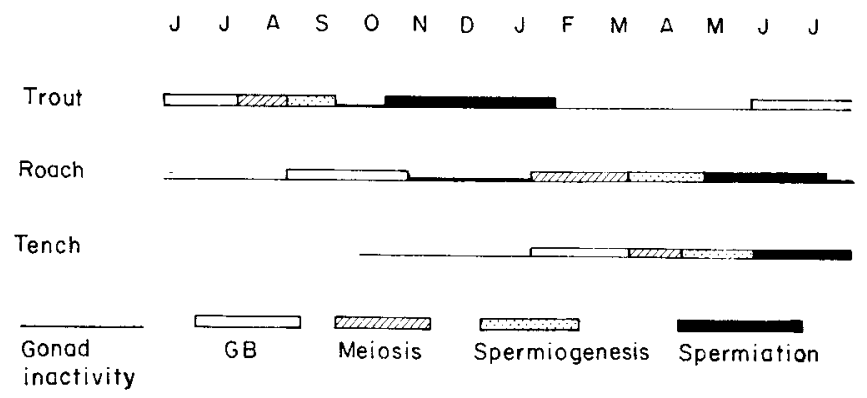

FIG. 8. - Position of various spermatogenetic events during the cycle in trout, roach and tench. 


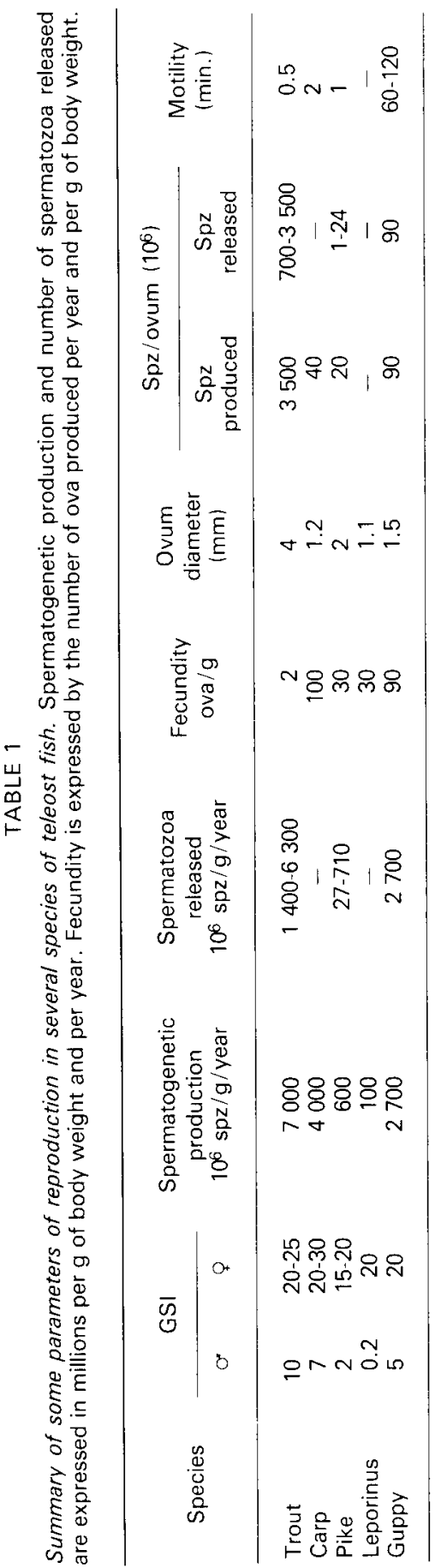


and pike with distinct spermatogenetic cycles, the residual spermatozoa are resorbed in the testis itself where they are phagocytosed by Sertoli cells (5) and by some macrophages identified in the lobular lumen $(4,21)$. Moreover, some spermatozoa are lysed in the lobular lumen (13). Lysis and resorption by phagocytosis also occur in the spermiduct (7).

\subsection{Conclusion.}

Spermatogenesis seems to be continuous in a species like guppy which has an original testicular structure consisting of tubules in which cysts move. This process is seasonal in such species as trout, carp and tench but occurs at different seasons; three groups can be distinguished which include a number of temperate zone species (41) (fig. 8) : group 1 (trout, carp, pike): spermatogenesis occurs in summer; group 2 (roach) : spermatogenesis begins in autumn but is interrupted in winter due to low temperatures and then recommences and terminates in spring; group 3 (tench) : the testes are quiescent in autumn and winter and spermatogenesis occurs entierely in spring.

While there is little difference in spermatogenetic production among the species (between 68000 and 150000 spermatozoa per day and per $\mathrm{g}$ of testis, or between 1.7 and $7.510^{6}$ spermatozoa per day and per $\mathrm{g}$ of body weight), the spermiation yield is much more variable (between 3 and nearly $100 \%$ of the spermatogenetic production). Although testicular weight alone is a good criterion of spermatogenetic production, it cannot be used to determine the efficiency of the male reproductive function, particularly the number of spermatozoa released during reproduction.

Spermatogenesis is a very diversified process in teleost fish, as seen above. This diversity is evident in the structures of the testis and genital tract, the dynamics of spermatogenesis - which may be continuous, quasicontinuous or very seasonal - spermatogenetic effectiveness (up to 14 spermatogonial generations), spermatogenetic production and spermiation yield.

This diversity also occurs in the morphology of the spermatids and the spermatozoa may reflect an adaptation to the various biotopes the fish have colonized.

We shall see how the different components of these diverse environments influence and determine the various phases of the reproductive function.

\section{Some aspects of the endocrine regulation of spermatogenesis and spermiation}

\subsection{Material and methods.}

Radioimmunoassay (34) and biological assay (35) of gonadotropins have been developed for endocrine studies by Breton and Jalabert, radioimmunoassay of androgens by Fostier (36) and the immunocytochemical analysis of pituitary cells by Dubois (37). The techniques of hypophysectomy (38), castration (39) and stereotaxy (40) have also been used. Hypophysectomy was widely practiced on guppy and goldfish but not in trout due to technical problems. Castration is 
difficult in cyprinids and has only been done in trout. Gonadotropins (glycoproteins) used for standard RIA and hormone supplements were provided as follows : Burzawa-Gérard (1973) : carp gonadotropin (cGTH) ; Breton et al., (1976) : trout and salmon gonadotropins (tGTH and sGTH).

\subsection{Profiles of trout and carp gonadotropins and androgens during the annual cycle.}

The study was based on regular samplings of plasma and pituitary at given times once or twice a month in rainbow and brown trout and in carp (25). In brown trout the levels of pituitary and plasma GTH rose markedly in April-May while testis weight was minimal ; GB first appeared at this time. During the rest of the cycle, pituitary GTH varied little but tended to increase during spermiation. Plasma GTH increased during spermatogenesis, reaching a maximum before spermiation began. Similar profiles were found in rainbow trout (25) where plasma GTH tended to decrease just before the first spermatozoa appeared in the spermiducts. Other experiments have confirmed this trend and showed that total androgen, and in particular 11-ketotestosterone $(11-\mathrm{KT})$, reached the highest peak at spermiation. The disappearance of $11-\mathrm{KT}$ from the plasma at the end of the cycle coincided with the arrest of spermiation (41).

\subsection{Endocrine control of spermatogenesis and spermiation.}

2.3.1. Spermatogenesis. - Hypophysectomy has shown that the dependence of various spermatogenetic stages varies with the species.

- In guppy the last spermatogonial generations degenerate rapidly when the pituitary has been removed. On the contrary, primary generations of $G B\left(G_{1}-G_{4}\right)$ disappear more slowly after hypophysectomy. Spermatocytes I do not develop into spermatocytes II and spermatids do not elongate. However, the GA's subsist in the apex and the first stages of meiosis do not seem to be pituitary-dependent (42); methallibure treatment does not inhibit spermatogenesis as much (43). Supplements of the crude pituitary extracts of gambusia, a species of the same group, maintain or at least qualitatively regenerate spermatogenesis in hypophysectomized guppies (44), and limited, partial regeneration is obtained with carp pituitary extracts and steroids (4-44).

- In goldfish, hypophysectomy carried out in full spermatogenesis causes a considerable decrease in testicular weight (4) and the total disappearance of all germ cells, except GA's and spermatozoa, within four weeks (45). A milder inhibitory treatment using methallibure showed that higher levels of gonadotropic hormones were needed to maintain spermatocytes and spermatids than to maintain GB's (46). Spermiogenesis did not require the presence of GTH (45). Some experiments on maintenance or restoration after hypophysectomy or methallibure treatment have shown that spermatogenesis is completely restored (45) by carp total pituitary extracts $(47-48)$ and by a highly purified gonadotropic factor (49). In goldfish, preparations of cyprinid crude pituitary gonadotropins seem to be more active than those of salmonids, suggesting specific zoologic activity (44). Mammalian gonadotropic hormones have no effect on spermatogenesis in goldfish; the GSI has been only partially maintained with HCG, but 
this hormone has no effect on the germ cells themselves. Testosterone in the form of propionate may maintain spermatogenesis after hypophysectomy but the dose varies with the stage : 1 to $10 \mu \mathrm{g}$ per injection are enough to maintain the GB's but $200 \mu \mathrm{g}$ are needed for meiosis and spermiogenesis (45).

2.3.2. Spermiation. - Goldfish spermiation is completely inhibited by hypophysectomy (50-51) and does not seem to occur when GTH levels decrease to less than $10 \mathrm{ng} / \mathrm{ml}$ with methallibure treatment (46). Intact males in captivity showing circulating levels of $8 \mathrm{ng}$ release no sperm (52). Hormone supplements given to intact or hypophysectomized males show that purified gonadotropic hormones and crude pituitary preparations as well as HCG markedly stimulate goldfish spermiation ; pituitary hormones other than GTH have little or no effect (50). Among the sex steroids, only methyltestosterone and progesterone have a clear effect (51). In carp, the injection of cGTH is followed by a temporary rise in $11-K T$, suggesting that this steroid mediates the action of GTH. Attempts to neutralize circulating GTH in trout by antibodies did not notably inhibit spermiation (fig. 9). However, GTH supplementation caused an increase in the volume of sperm released (4). Supplements of testosterone and 11-KT in the form of silastic implants in the testes had no marked effects on spermiation (4) but the

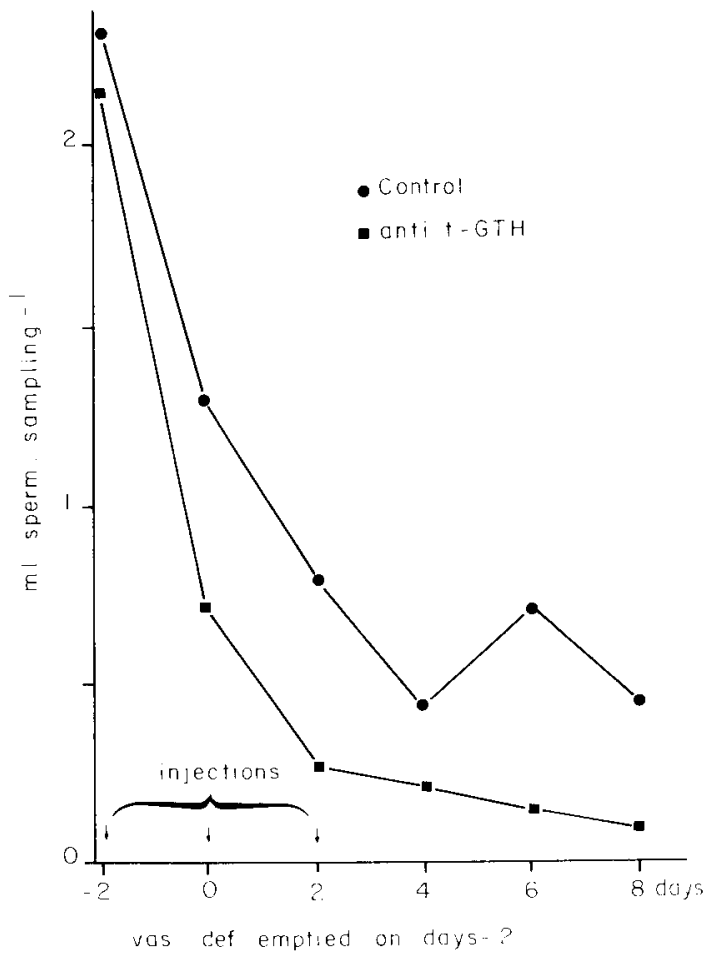

FIG. 9. - Effect of anti-tGTH administration $10.1 \mathrm{ml} / \mathrm{kg}$ ) in rainbow trout in mid-spermiation on the volume of sperm released. Sperm was collected from Day 2 before the first injection. (In collaboration with G. de Montalembert and B. Breton). 
levels of the steroids released might not have been high enough. In pike, the administration of pike or carp crude pituitary extract (53) or of progesterone (54) stimulated spermiation while testosterone and HCG had no significant effects.

2.3.3. Conclusion. - The degree to which spermatogenesis depends on the pituitary varies with the spermatogenetic stage. GA morphology or physiology is not affected by hypophysectomy since the GA's are restored after the operation. However, GB development, especially in the older generations, is pituitarydependent. The same is true of meiotic prophase.

Guppy spermiogenesis seems to require gonadotropin but goldfish spermiogenesis does not. This points to species differences that correspond with differences in the complexity of spermiogenesis, goldfish, as carp, producing only round spermatids which show little transformation until sperm are formed.

The maintenance of spermatozoa in the lobules or the testicular duct of guppy does not require the presence of GTH since spermatozoa subsist after hypophysectomy; their fertilizing ability has not been tested.

The specific zoological action of gonadotropins is clear in HCG which cannot maintain or restore spermatogenesis in hypophysectomized goldfish. This conclusion has not been confirmed in eel because HCG induces complete spermatogenesis in the hypophysectomized animal (Khan, 1983). The existence of zoological specificity within the same teleost group, suggested by this work, has yet to be confirmed by using purified preparations of known biological activity and a more complex approach, as for example, in vitro studies.

Spermiation is initially gonadotropin-dependent but, contrary to carp, trout does not need high amounts of -GTH to maintain this activity: It should be pointed out that after injection of gonadotropin a rise of $11-\mathrm{KT}$ and $17 \alpha-20 \beta$ dihydroxy-4-pregnen-3-one (17 $\alpha-20 \beta \mathrm{P}$ ) (Scott and Baynes, 1982) is observed. As injection of 11-KT was not followed by a stimulation of spermiation, it seems likely that $17 \alpha-20 \beta \mathrm{P}$ is more directly involved in this process. In fact, progesterone was shown to have some effect on spermiation.

Differences between trout and carp as to the gonadotropic determinism of spermiation suggest divergent regulations which will be examined in relation to their physical and social environments.

\subsection{Feedback of the male gonad on the hypothalamo-pituitary axis.}

Before analysing the stimulatory, inhibitory or synchronizing effects of the external environment on the male reproductive function, it is necessary to understand how the central nervous system and the pituitary perceive information from the testes or other organs, both adult and juvenile; the prepuberty possibly correspond to a period of sexual quiescence in seasonally reproducing species.

Bilateral castration causes a rise in circulating GTH in adult rainbow trout but its amplitude and duration of response vary with the cycle stage (55-56). Supplements of estradiol $\left(E_{2}\right)$ and testosterone (T) given to castrated or intact males affect the levels of circulating GTH which also vary with the cycle stage. In March during sexual rest, castration causes a rise in GTH which is not inhibited by $T$ implant ; when $T$ is implanted in intact animals, GTH also increases (55). In 
June, when spermatogenetic activity intensifies, the GTH rise after castration is inhibited by $E_{2}$ and $T$. In full spermiation in December, the strong reaction to castration is only partially inhibited by implants of $T$ and $E_{2}$ in the general cavity and by $11-\mathrm{KT}$ in the pituitary, but this reaction is not significantly modified by testicular extracts, whether they contain steroids or not (55). On the contrary, administration of a factor extracted from seminal fluid and treated with charcoal partially inhibits the GTH rise which follows castration (56).

Hemicastration in May causes no changes in the levels of circulating tGTH while bilateral castration results in an increase ; after hemicastration, the contralateral testis shows compensatory hypertrophy and its weight is equal to the sum of the two testes of the intact controls.

Testicular fragments invisible to the naked eye and resulting from incomplete bilateral castration carried out on male trout in May, regenerated testes in September that weighed the same as those of the sham-operated control fish.

Thus, the gonad seemed to act on the higher centers by modulating pituitary gonadotropin secretion ; this modulation varied with the stage of the reproductive cycle. Non-steroid factors, perhaps of an inhibin-type, appeared to be involved, and we wished to test the putative role of androgens on both spermatogenesis and the regulation of gonadotropin secretion by continuously administering antiandrogens (cyproterone acetate and oxymetholone) in the feed of intact male trout. Testicular growth was inhibited when the treatment began in May before the active phase of spermatogenesis was initiated (57). Measurements of circulating GTH showed that the concentrations tended to be substantially higher in treated than in untreated fish. If the treatment began in June, after testicular growth had started, it had no effects on either spermatogenesis or plasma GTH concentrations (57). This experiment shows that the anti-androgens had a direct effect on the gonad before spermatogenesis was established. The effects of the gonad on the central level could thus vary during the annual cycle.

In trout juveniles several months old and weighing more than $10 \mathrm{~g}$, the testis reacted to a $\mathrm{sGTH}$ injection by producing testosterone and 11-KT. At the same time, the pituitary level of GTH increased; this did not occur in the castrated controls (58). Intraperitoneal implantation of testosterone, $E_{2}$ and cortisol in juveniles also caused a rise in pituitary GTH $(59,60)$. It can therefore be concluded there was positive gonadal feedback on the pituitary. However, juveniles castrated when immature showed a pituitary GTH level one year later that was comparable to that of the sham-operated controls which were then mature. The castrated animals also showed higher levels of circulating GTH than the controls (61), suggesting that a negative feedback was established. Removing the gonad thus does not inhibit the rise in pituitary GTH over a long period but it is possible that non-sexual steroids, such as cortisol, might be involved since cortisol could increase the level of pituitary GTH if implanted in the pituitary (59).

The sites and modes of the action of steroids and other gonadal factors have not been studied in detail. In the case of cortisol, the effects differ with the administration site : intraperitoneal injection to juvenile trout has no effect on the rise in pituitary GTH, contrary to an intrapituitary implant (59). Testosterone and $E_{2}$ are effective in both cases (59). The action appears to be centered in the 
pituitary. In adult goldfish which show a negative estrogen feedback on central levels $(60)$, the site of action is mainly in the pituitary and less in the hypothalamus (60). It may be that the steroid effect seen in the pituitary does occur in neuroendocrine components such as the $\mathrm{LRH}$ fibers that are abundant in that gland (62).

In conclusion, the type of testicular feedback on the hypothalamo-pituitary axis in trout is not the same in adults in spermatogenesis and spermiation as in those in sexual rest and in immature juveniles. However, in all cases the testis is receptive to gonadotropic stimulation, indicating that the reasons for sexual inactivity are to be found at high levels such as the pituitary and the central nervous system ; these latter appear to be subject to endocrine control as well as exogeneous factors.

\subsection{Effect of some environmental factors on spermatogenesis and spermiation}

The effect of the environment varies according to the species and the development of the testis (spermatogenesis or spermiation).

In tench, increasing the rearing temperature of $6{ }^{\circ} \mathrm{C}$ accelerates the process of spermatogenesis $(27) ; 700$ degrees-days are needed to initiate spermatogonial division and 1000 degrees-days for spermiogenesis.

In goldfish, the temperature plays a major role in spermatogenesis; after 3 months of rearing under long days (16L : 8D) and at $30^{\circ} \mathrm{C}$ between February and May, only GA's are found in the testes while GTH levels remain high in the plasma and pituitary (63). Spermatogenesis occurs normally at temperatures between 10 and $24{ }^{\circ} \mathrm{C}$, but if rearing at $30^{\circ} \mathrm{C}$ is continued beyond the month of May, spermatogenesis is reinitiated 7 months later. The GSI is then higher in males kept under 16L : 8D than under 8L : 16D (64). Photoperiod has little effect on spermatogenesis in goldfish but in general long days are more favorable than short ones (65). Among other factors influencing spermatogenesis and spermiation are feeding and the concentration of dissolved $\mathrm{O}_{2}$. A fast of 3 months causes the testes to regress at 12 as at $20^{\circ} \mathrm{C}(65)$. Spermatogenesis, complete at $5 \mathrm{mg}$ of $\mathrm{O}_{2} /$ liter, is inhibited when the concentration drops to between 1.5 and $3 \mathrm{mg}(64)$.

Goldfish do not spermiate under a constant rearing temperature $(10,17$, $24^{\circ} \mathrm{C}$ ) but in a natural environment, fluctuating temperatures favor spermiation (52). The social environment is also important. In goldfish, GTH levels and spermiation are stimulated after the males are put with females (66). The same is true for carp.

In rainbow trout, spermatogenesis occurs within a wide temperature range $\left(8-18{ }^{\circ} \mathrm{C}\right)(67,68)$, but needs a well-defined photoperiod as, for example, a regime decreasing from $16 \mathrm{~L}: 8 \mathrm{D}$ to $8 \mathrm{~L}: 16 \mathrm{D}$ in 6 months $(68,69)$. During spermiation, environmental requirements seem to be the opposite; the photoperiod has no effect while at rearing temperatures of $15-18^{\circ} \mathrm{C}$ the volume of released sperm is lower than at $10^{\circ} \mathrm{C}(67)$. When the temperature is raised from 10 to $18^{\circ} \mathrm{C}$; heat shock causes a considerable rise in plasma GTH but spermiation is not intensified (fig. 10) (67). 


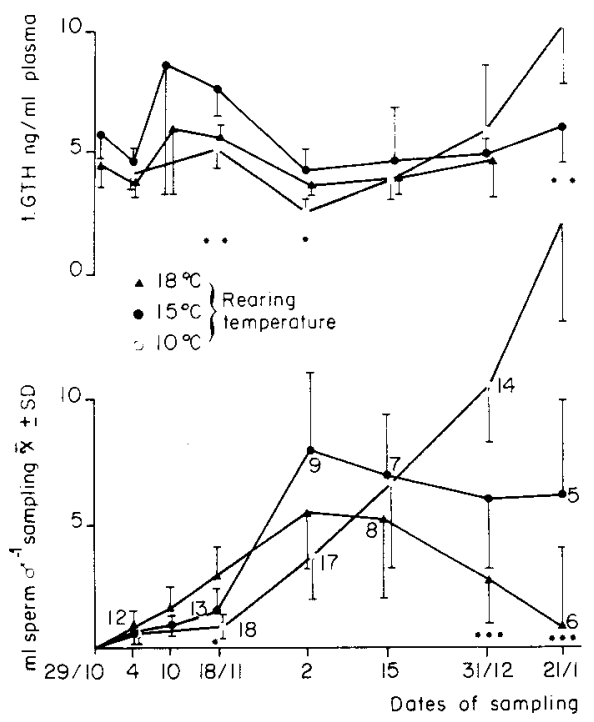

FIG. 10. - Profile of plasma tGTH and of the volume of sperm collected in 3 groups of rainbow trout under different temperature regimes.

\subsection{Attempts to control spermatogenesis and spermiation.}

When the above-mentioned decreasing photoperiod is advanced in rainbow trout for example between January and June, spermatogenesis is advanced as well as spermiation. Early spermatogenesis can be experimentally induced in juvenile trout by repeated sGTH injections $(70)$ or by intraperitoneal implant of $200 \mu \mathrm{g}$ of testosterone in cocoa-butter. When various sex steroids are incorporated in the feed and given continuously for 150 days from the first feed intake, sex reversal, hermaphrodites and sterile individuals result (71). When a similar treatment is given to adults from the onset of spermatogenesis, that process is inhibited and severe testicular necrosis results $(72,73)$.

Theoretically, there are several ways of controlling spermatogenesis : by advancing or inhibiting it and by reversing the sex. Some, such as advancement by modifying the photoperiod, have been used in practice ; others, such as sex reversal, have opened interesting perspectives in the genetic control of sex.

As concerns spermiation, it is necessary to be able to stimulate sperm release in species with low spermiation yield. This implies better management of brood fish in hatcheries. Gonadotropic treatment, i.e. carp pituitary extract for pike (43) or LHRH-A combined (74) or not (75) with pimozide for carp (which suppress the dopaminergic inhibition of GTH secretion), increases the volume of sperm available for insemination.

\subsection{Conclusion.}

Spermatogenesis and spermiation depend on such diverse environmental factors as photoperiod, temperature, dissolved $\mathrm{O}_{2}$ and the social milieu but their effect differs with the species. In carp, spermatogenesis is initiated immediately 
after spawning, but no clear GTH variations are observed. The effect of photoperiod has not been studied much in carp, but it is generally conceded that gametogenesis in species reproducing in spring or summer is stimulated by long photoperiods (Lam, 1983). In trout a GTH peak in spring precedes the onset of spermatogenesis. This GTH surge, which occurs at the same time in the pituitary and plasma, could be due to such an environmental factor as exceeding the critical daylength. Spermiation depends more on temperature than on photoperiod. Low temperatures favor trout spermiation while high and sometimes fluctuating ones favor cyprinid spermiation. In the latter, social factors such as the presence of females are also important.

\section{Data concerning sperm physiology}

\subsection{Material and methods.}

Sperm motility is evaluated microscopically by reference to an arbitrary scale which associates motility intensity with the percentage of motile spermatozoa (76). More objective techniques, such as inelastic light diffusion (77) and stroboscopy, have also been used to analyse the beating frequency of the flagellum.

Fertilizing ability is determined by inseminating lots of about 200 ova with a given amount of sperm (sperm dilution : $10^{-2}-10^{-4}$ ) in a diluent. The percentage of eyed-eggs gives the approximate fecundation percentage.

\subsection{Motility.}

3.2.1. Duration of motility. - The spermatozoa of teleosts are immotile in the genital tract and only become motile after dilution in the external medium or after they are put into the female genital tract, as in viviparous species. The factors inhibiting motility are $\mathrm{K}^{+}$in salmonids and osmotic pressure in cyprinids. The duration and intensity of motility vary according to species, temperature and diluent composition and may fluctuate during spermiation. Spermatozoa survive only a short time in fresh water (about $1 \mathrm{~min}$ ) and considerable structural modification may occur, including even plasma membrane rupture (78). The motility of the spermatozoa of some sea fish is also brief in salt water of $35 \%$ salinity but structural changes are not as marked. Generally, when isotonic physiological solutions are used to dilute the sperm, sperm structure is not modified (78) but motility time still varies greatly, lasting 1 to $2 \mathrm{~h}$ in guppy vs only one or several minutes in other species. After the spermatozoon swims for $30 \mathrm{~min}$, the amount of glycogen in the mid-piece is considerably depleted (79).

3.2.2. Motility and fertilizing ability in rainbow trout. - There is no clear relationship between motility estimated under a microscope and fertilizing ability (80). On the other hand, changes in the beating frequency of flagella after dilution do correspond to changes in fertilizing ability (fig. 11). The frequency measured at $20^{\circ} \mathrm{C}$ is $50 \mathrm{~Hz}$ at the onset of motility (fig. 11) (80) and it decreases linearly to $15 \mathrm{~Hz}$ in $30 \mathrm{sec}$ : a second phase then begins in which only a part (50\% or less) of the spermatozoa remains motile for 1 or more min with beating frequencies of 

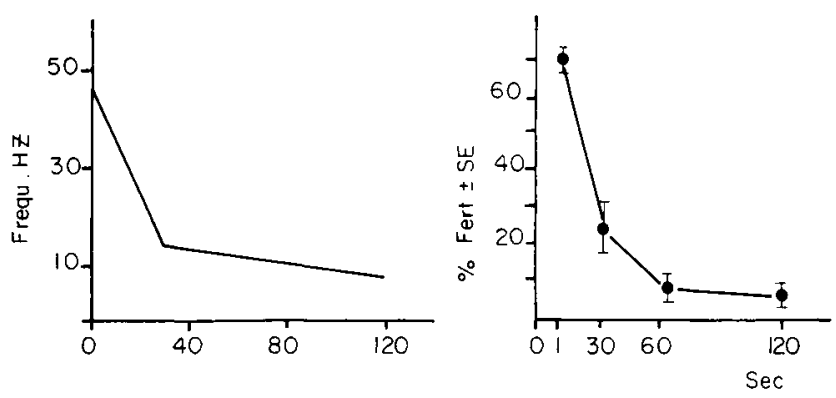

FIG. 11. - Changes with time in the beating frequency of flagella (in $\mathrm{Hz}$ ) and in the fecundation percentage of trout spermatozoa after dilution (dilution rate : 1/1000 at insemination).

about 10-15 Hz. These spermatozoa may fertilize ova but only when the dilution rate is low. It is thus understandable that increasing the number of spermatozoa may compensate for the decrease in motility. This has been clearly observed after deep-freezing when thawed spermatozoa showing short, low motility can fertilize the same proportion of ova as untreated spermatozoa, if the number used to inseminate is 10 -fold higher (81). This may be due to the fact that the spermatozoon can penetrate the ovum at only one place, i.e. through the micropyle ; the chances of fecundation depend on the distance the spermatozoon must cover to reach the micropyle and possible on the form of its trajectory. The lower the motility of the spermatozoon, the less distance it can cover; this can be compensated for by increasing the sperm concentration.

3.2.3. Effect of sperm age. - In species with discontinuous reproduction, the spermatozoa all appear over a relatively short period of one month. However, they are released over several months, that is they age as the reproductive period advances. This aging process is particularly evident in sea-bass since motility time and intensity decrease rapidly in one month (83) as well as sperm fitness for storage and deep-freezing (84). cAMP stores, motility time and fitness for storage and deep-freezing also decrease in trout at the end of spermiation.

Moreover, at the onset of spermiation, the fertilizing ability of the spermatozoa is different at various genital tract levels ; this ability is higher in the spermiducts than in the testes (82). This would support the hypothesis of extratesticular maturation; it should be noted that the more concentrated intratesticular spermatozoa are not "protected " by the seminal fluid (see below).

3.2.4. Effect of dilution medium composition. - Experiments on spermatozoa washed in potassium-rich $(50 \mathrm{mM})$ media to prevent the initiation of motility have shown that elimination of the seminal fluid and washing causes a decrease in fertilizing ability $(85,86)$. This process is amplified even more if the ova are also washed (87). It is thus evident, at least in trout, that the seminal fluid besides immobilizing the spermatozoa also protects them. The levels of minerals and amino acids in the seminal fluid of trout $(88,89)$ and carp $(90,91)$ show wide species differences and very original compositions; the amino acid levels of the seminal fluid are almost 400 -fold higher in carp than in trout. It has been experimentally proven that adding BSA to the saline solutions enhances trout 
sperm survival and allows an increase of the dilution rate, i.e. that each ovum can be fertilized using fewer spermatozoa (86). In carp, in which sperm motility is inhibited by the osmotic pressure of the seminal fluid, the osmotic contribution of the mineral fraction alone is not enough because sperm motility can be initiated in a saline solution that re-constitutes the mineral composition of the seminal fluid. To obtain total inhibition the osmotic contribution of the peptide part must be added.

The oxygen level of the medium is also important in sperm survival, at least in salmonids. Although the respiration of both immotile and motile spermatozoa is low, in vitro storage under $\mathrm{O}_{2}$ prolongs the conservation time (92, 93). Furthermore, spermatozoa do not survive in the genital tract for more than several hours after a male rainbow (94) or fario (95) trout is killed, while an aliquot of their sperm can be stored several days in vitro.

The $\mathrm{pH}$ of the external medium plays a determinant role in the motility of trout spermatozoa. At $\mathrm{pH} 7$ or less, the spermatozoa are immotile and at $\mathrm{pH} 9$, motility intensity is maximal (fig. 12). The internal $\mathrm{pH}$ of the spermatozoa varies in parallel with the external $\mathrm{pH}$ and is about $1 \mathrm{pH}$ unit less (Christen et al., unpublished data). When media are buffered at different $\mathrm{pH}^{\mathrm{s}} \mathrm{s}$ for insemination, maximal fertility rate is between $\mathrm{pH} 8$ and $9.5(96,97,98)$.

3.2.5. Effect of temperature. - Temperature has a strong influence on sperm motility and fertilizing ability in rainbow trout. The beating frequency of the flagella is low at $5{ }^{\circ} \mathrm{C}$; it increases rapidly at about $10^{\circ} \mathrm{C}$ and is maintained at $50 \mathrm{~Hz}$ up to $20-25^{\circ} \mathrm{C}(80)$. When insemination is carried out within a temperature range of 1 to $20^{\circ} \mathrm{C}$, the fertility rate is highest at $5^{\circ} \mathrm{C}$ and at $10^{-4}$ to $10^{-5}$ dilution (99). At $0-5^{\circ} \mathrm{C}$, the in vitro storage time of the spermatozoa is prolonged (76). High intermale variability in sperm reponse to temperature is without doubt related with differences in sperm quality $(67,80,99)$.

3.2.6. Effects of micropollutants on spermatozoa. - The spermatozoa of species with external fertilization, such as trout, are vulnerable to micropollutants like PCB (100), lindane (101) and heavy metals (102) or other compounds like fatty alcohols (103). The effect of these micropollutants is amplified when the temperature rises (101). Pesticides like parathion inhibit spermatogenesis in guppy

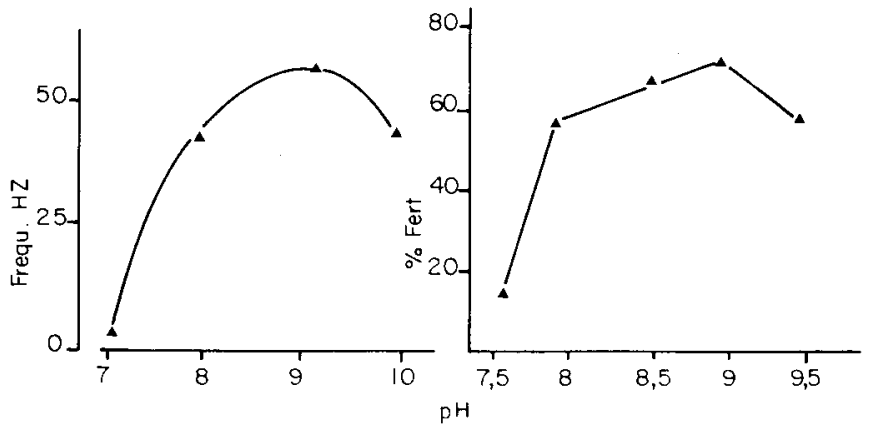

FIG. 12. - Changes in flagellum beating frequency and fecundation percentage of rainbow trout spermatozoa diluted in media buffered at different $p H$ 's. 
(104). Most of these effects occur at low doses which do not kill the larvae or adults. Fish spermatozoa and even spermatogenesis are thus sensitive to anthropic changes in the environment.

\subsection{Data on sperm metabolism.}

The ATP stores of rainbow trout spermatozoa are quickly depleted after motility begins. This internal ATP decreases from 2 to $0.3 \mathrm{mM}$ in one min then regenerates in the following minutes, although motility is not re-initiated and the flagellar mechanism continues to function. Once motility is initiated and then stops, sperm flagellar beating can be re-initiated after the sperm membrane has been removed by a detergent and the sperm diluted in a reactivation medium containing $\mathrm{Mg}^{++}$, ATP and cyclic AMP.

The addition of theophylline to the dilution medium may prolong motility and fertilizing ability (105), but this type of motility is similar to the residual motility observed after $30 \mathrm{sec}$ with low flagellar beating frequencies (fig. 11).

\subsection{Conclusions.}

The gametes of freshwater species with external fecundation are released into a particularly hostile medium. In a few minutes, the spermatozoon is hydrated so that its plasma membrane may rupture. The egg, however, is protected against hypo-osmotic shock by the cortical reaction related with ionproton exchange that renders the plasma membrane-chorion-perivitelline space complex impermeable. This process also blocks the micropyle in several minutes, making further fecundation impossible. As the gametes are released synchronously, the spermatozoon needs only a brief time to fertilize the egg; this would explain why such spermatozoa have short motility time, no extensive energy stores or elaborate metabolic mechanisms, and no device for resisting hypotonicity.

On the other hand, guppy spermatozoa, which have no contact with the external medium and are transmitted to the female in a spermatozeugma, show longer motility coupled with stores and a more complex metabolism. They are especially suited to internal fecundation.

\section{Discussion.}

Testicular structure has been discussed recently by Grier et al. (1980) and Grier (1981) who divide teleost testes into two groups, restricted and unrestricted, based on the distribution of stem spermatogonia; these groups correspond to tubular and lobular-type testes, respectively. The restricted type has been extended to include the whole atheriniform group. Brock (1978) identified two types of lobular-type structure, acini in cyprinids and tubules in percoids, but Roosen-Runge (1977) noted that these two forms represent two extremes of the same type. In fact, syngnathids have an even simpler testicular structure in which the gonad is reduced to a tube which has few connective extensions and is very short (fig. 13). The tubular-lobular distinction probably corresponds to two 
filiations, one the tubule type (not found in higher vertebrates), and the other the lobule type which announces amniote structure.

In mammals, connective tissue extensions originating from the testicular capsule delimit lobules in which the germ tissue is no longer apposed to the walls but to the inside of a neoformation called the seminiferous tubule. This complex in the efferent system is also complicated by the appearance of a rete-testis (fig. 13). The term seminiferous tubule cannot then be used in fish.

The existence of interstitial cells (identified by morphological criteria) in the interlobular or intertubular space and of a Sertoli-germinal compartment does, however, relate the fish testis to the type of structure found in vertebrates.

Not being able to find interstitial cells in the interlobular space of some fish species (for example, pike), Lofts and Marshall (1957) attributed steroidogenic function to the somatic cells in the germinal compartment, calling them "lobule boundary cells ". Since then, interstitial cells have been identified in all species studied (Gresik, 1975 ; Nagahama et al., 1978 ; Grier et al., 1980; Van den Hurk et al., 1982), including pike (6). At present, authors do tend not to use the terminology of Lofts and Marshall but refer to the cells as Sertoli cells (5) (Gresik et al., 1973 ; Gardiner, 1978a ; Grier, 1976, 1981 ; Nagahama, 1983). The use of « cyst cell » proposed by Roosen-Runge (1977) and mentioned by Gresik et al. (1973) and (4), has not been retained. The steroidogenic function of the interstitial cells has been reviewed and discussed by Fostier et al. (1983).

The origin of Sertoli cells in teleosts has not been thoroughly described. In species with lobular testes such as trout, the female gonad is easily identified by the appearance of meiosis at about 6 to 10 weeks after hatching, while the male gonads are those which remain undifferentiated beyond 10 weeks (Takashima et

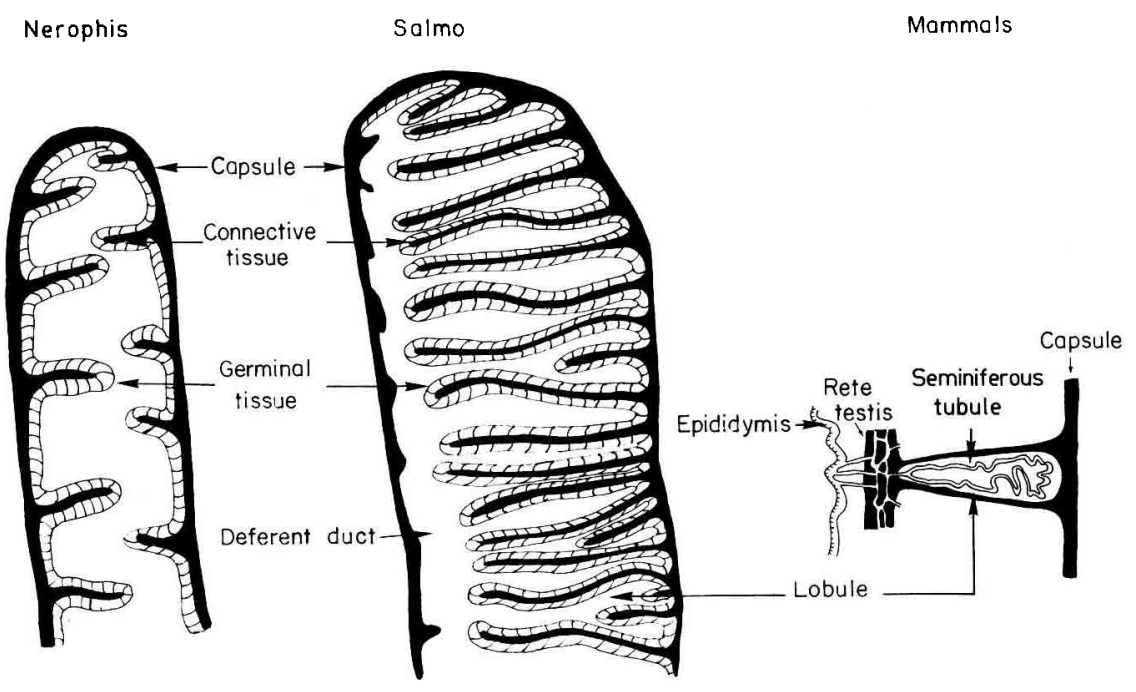

FIG. 13. - Testicular structure in syngnathids (Nerophis) (from Guyomarc'h, 1970) and Salmonids. A comparison with the mammalian structure in which the extension of the testicular capsule also delimits lobules in which the seminiferous tubules are inserted (from Davis et al., 1970). 
al., 1980) (9). In the latter, various types of somatic cells have been identified among the germ cells (primordial germ cells and gonocytes) (9). Among the somatic cells are Sertoli cell precursors which correspond to stem cells in mammals. At 1 to 2 years of age, the lobule precursors appear in the form of tube having a central lumen bordered with somatic cells (corresponding to Sertoli cells); these somatic cells are associated with germ cells. The same lobule precursors are also found in juveniles (rainbow trout : Magri, 1983 ; eel : Khan, 1983) after gonadotropic hormone administration. In species with tubular testes, as guppy, the somatic cells are associated with germ cells as soon as the apex of the immature gonad is formed, and this association continues to exist in adults. These cells are probably equivalent to Sertoli cells. Below the apex, the number of Sertoli cells surrounding the cysts increases as spermatogenesis progresses. According to Billard (8), these cells degenerate at the end of spermatogenesis or they may be included in the epithelium of the efferent ducts (Van den Hurk et al., 1974 ; Grier et al., 1978) so that there is no permanent Sertoli epithelium in tubular testes. This led to the presumption that Sertoli cells are renewed in adults. Although tritiated thymidine has been incorporated into Sertoli cells (Felice and Ralsh, 1969), no mitotic structures were found (1), indicating an extratubular supply in the form of fibroblasts, for example. Between the undifferentiated stage and lobule formation, testis size and the number of somatic cells augment. It is probable that stem cells multiply actively before lobule formation, i.e. at the onset of puberty. This multiplication may also be gonadotropin-dependent. Sertoli cell increase has not been demonstrated in adults. However, the testis regeneration obtained after hemi-castration or sub-total castration in adults indicates that there is considerable cell multiplication compared to that in juveniles. Unless there is an extratesticular cell supply, there must be considerable stem cell and Sertoli cell renewal in trout.

The renewal ability of testes after partial castration raises several questions. Testis structure appears to be almost normal when there is regeneration, indicating that the various components have been renewed. When only one testis is removed and compensatory hypertrophy results, the lobules tend to be larger but it cannot be determined if this increase in size is due to new spermatogenetic waves or to better spermatogenetic yield because of reduced degeneration. But when a small fragment of testis shows almost complete renewal, it must be considered as due to multiplication, unless there is an extratubular supply of somatic cells. Moreover, incomplete castration in adult trout after the postmeiotic stages does not cause autoimmune-type alterations in spermatogenesis after destructuration of the lobules; in salmon, testicular extracts cause autoimmune destruction of the male gonads (Laird et al., 1978).

The arrangement of Sertoli cells in the lobules is quite different from that in the seminiferous tubules of higher vertebrates. In lobular testes, the germ cells, including the GA's, are always embedded in the Sertoli cells and are never in contact with the basal lamina ; there is no basal compartment, only an adluminal one. However, due to tight junctions between the Sertoli cells, a testis-blood barrier has been observed in several species; this barrier appears at different stages in different species, i.e. at meiosis in guppy (Marcaillou and Szöllösi, 1980) 
and later after spermiogenesis in Aphanius dispar (Abraham et al., 1980 ; also see Bergmann et al., 1984).

The endocrine function of the Sertoli cells is still not clear in fish. Criteria for defining its steroidogenic activity (metabolism or synthesis) are relatively limited and consist of histoenzymological evidence of various enzymes or the presence of lipids (Mattei et al., 1982). At present, there is not clear answer to the question of whether the Sertoli cell is the target of a gonadotropic hormone and, if so, which hormone. Only an in vitro study using isolated Sertoli cells can provide a valid answer.

In lobular and tubular types, germ cells occur at various sites; the GA's are isolated, the GB's, spermatocytes and spermatids are found in cysts, and the spermatozoa are grouped at the base of tubules but are free in the lumen of globules. The term " GA " probably includes several types of cells that have not been distinguished by morphological criteria. Their number remains almost constant during the annual cycle, although it increases in some species such as carp. Such an increase could mean the appearance of intermediate spermatogonia. The mode of GA renewal is controversial, some authors are of opinion they are of extralobular origin (Van den Hurk et al., 1978) and suggest that the Sertoli cells send extensions outside the lobules to gather the stem spermatogonia (Ruby and McMillan, 1975). However, many authors think that the GA's are renewed from a stock that is permanently present inside the lobules; we agree with this hypothesis proposed by Wiart (1936) because we have never observed GA's in the extralobular or extratubular space in any of the species we have studied. It is often believed that primary germ cells (PGC) and GA's are characterized by the presence of ringed lamellae and granular material associated with mitochondria (Nagahama, 1983). However, these structures are also found in GB's and granular material even occurs in spermatocytes.

The grouping of germ cells into cysts is considered to be characteristic of anamniotes. The cells in the group develop isogenically from a GA spermatogonia. However, Bruslé (1982) studying Liza aurata and Wiebe (1968) Cymatogaster aggregata reported that the cells were organized into cysts only at the spermatocyte stage. In the latter species, Gardiner (1978b) observed spermatogonia in cysts. In the species described in the present paper, the spermatogonia that were linked together by intercellular junctions were grouped into cysts with a syncitial structure. The concept of groups of isogenic cells having cytoplasmic continuity is general (Roosen-Runge, 1977) and is also applied in mammals (Dym and Fawcett, 1971) although the cysts are not morphologically identifiable.

The number of spermatogonial generations (fourteen) is very high in guppy ; similar values (ten-twelve) were found in gambusia, another species with tubular testes, but they are lower in species with lobular testes (Roosen-Runge, 1977). Higher values were reported in Scleropages by Scott and Fuller (1976). Generally, PGC multiplication is high in fish. About 50 PGC's are found in the undifferentiated gonad of the juvenile trout and 8 to $80.10^{6} \mathrm{GA}$ in the adult testis (13); this is equal to at least 17 divisions. The process is even more marked in the capacities of trout for compensatory hypertrophy; when a testis is removed at the 
beginning of the cycle, the remaining testis doubles in size at the end of spermatogenesis, giving a GSI comparable to the controls. When prepuberal juvenile trout are castrated under a binocular, castration sometimes proves to be incomplete and the remaining bits of gonad regenerate testes of a size and structure comparable to the controls (61). It is hypothetised that PGC may actively contribute in the adult testis and might also explain the presence of previtellogenetic oocytes in adult testes (unless oocytes in meiosis have subsisted from the juvenile gonad) or the presence of small testicular nodules sometimes found in the ovaries. Such PGC's have been described in the gonads of adult mugilids (gonochoric) and serranids (hermaphrodites) by Bruslé (1982). Michibata (1975) distinguished stem $(3-4 \mu \mathrm{m})$ and differentiated $(5-10 \mu \mathrm{m})$ spermatogonia.

Primordial germ cells or undifferentiated gonocytes present in adults might multiply many times, more than the spermatogonia whose number of divisions is better defined.

While overall cell morphology is comparable among species up to the spermatocyte stage, notable differences appear at spermiogenesis. This point has been thoroughly discussed (Billard, 8, 10, 13) in relation to the final morphology of the spermatozoon and its physiology (see below). The degree of chromatin condensation and of nuclear change is more marked when spermiogenesis is complicated. The significance of these structures is still not well known.

It is necessary to question the resistance of the sperm structure to manipulation. For example, it has been shown that after deep-freezing, the chromatin of trout spermatozoa is modified. This may be why a large number of carp motile spermatozoa lose their fertilizing ability after deep-freezing, and it is not sure that these alterations would not cause chromosome anomalies in the progeny.

The most complex spermatozoa with an elongated nucleus and developed mid-piece are not found exclusively in species with lobular testes ; they also occur in other groups such as Cymatogaster aggregata, a viviparous perciform. Gardiner (1978a) studying this species concluded that the elongated head and mid-piece were specialized for internal fecundation. In the anterior part of the spermatozoa, specialized areas have been described in some species such as viviparous Xiphophorus helleri in which lectins are specifically bound at an exact point in the plasma membrane having a glycocalyx that adheres closely to the nuclear envelope (Jonas-Davies et al., 1983). These lectins, concanavalin A and Ricinus communis, indicate the presence of D-mannosyl and D-galactosyl residues. The plasma membrane of trout spermatozoa is also closely apposed to the nuclear envelope which itself adheres to the chromatin lamina inside the nucleus (13). The specialized area probably represent sites at which the membrane fuses at fecundation. This type of plasma membrane anchorage to the nuclear envelope, observed in trout, may also represent an adaptation to the mode of fertilization in which the spermatozoa rest a short time in the water; the anchorage would prevent the plasma membrane from detaching from the nucleus after hypoosmotic shock.

The fish spermiduct appears to have a composite structure. The free, wellindividualized part between the testis and the genital papilla is thought to be a neoformation originating in the urogenital area, while the intra or juxtatesticular 
part which varies in morphology and position is not very structured, being a testicular area with no germinal epithelium (Grier et al., 1980). In carp, Dragotoiu (1963) reported that the two spermiducts met between the intestine and the urinary bladder in a single short tube having no musculature but a common outlet with the urethra. This poses the question of the mode of " ejaculation " and of a putative urinary sperm supply.

Due to its limited extension, the carp spermiduct is not as well developed for storage as in trout. However, in the goldfish, another cyprinid, ventral extensions of the juxtatesticular part of the spermiducts have been interpreted by Takahashi and Takano (1972) as a sperm reservoir. Besides the function of sperm storage attributed to spermiducts, the literature also mentions the function of residual spermatozoon resorption (Hayashi, 1969) and the secretion of protein-like seminal material $(\mathrm{pH} \mathrm{6.5)} \mathrm{that} \mathrm{contributes} \mathrm{to} \mathrm{spermatophore} \mathrm{cohesion} \mathrm{in} \mathrm{the} \mathrm{viviparous}$ fish, Cymatogaster aggregata (Gardiner, 1978b). After transfer into the female genital tract, the spermatozoa dissociate from the spermatophores when the $\mathrm{pH}$ is higher than 7.3-7.9 and they are in the presence of ovarian fluid (Gardiner, $1978 b)$. In view of results obtained in trout, spermatophore dissociation in C. aggregata may be due to the initiation of sperm motility due to the higher $\mathrm{pH}$.

The spermatozoa of viviparous species are transferred directly into the female genital tract and seem to have no contact with the exterior medium. Specialized structures at the anal fin (gonopod) consit of a simple groove in species where the spermatozoa are grouped into spermatozeugmas or spermatophores and of a real tube in species where the spermatozoa are free, as in the atheriniform, A. anableps (Grier et al., 1981). Thus, the spermatozoa of viviparous fish are not necessarily grouped together but when they are free, the transfer structures in the gonopod are more elaborate. Atheriniform testes (" unrestricted " or tubular) can also produce free spermatozoa. Moreover, viviparous species, such as $C$. aggregata which is a perciform, are found in other groups than atheriniforms.

The reproductive cycle includes two main events, spermatogenesis and spermiation, that appear to differ greatly as to length, endocrine determinism and modulating environmental factors, the two latter being subject to family variation. Spermatogenesis and spermiation and, more generally, gametogenesis and gamete release-fecundation, can occur continuously as associated events or, on the contrary, as events separated by a more or less long time interval and thus dissociated. Some of the species studied may be included in Crews' (1984) plan.

Different combinations are found which suppose, in the case of discontinuity, that there are some particularities, especially in relation to the storage fitness of one of the gametes while waiting for its sexual partner to be available and/or for environmental conditions to be favorable for reproduction.

During spermatogenesis, basic plasma GTH levels are low. The pulsatile character of this secretion has not yet been clarified in males ; in male trout Zohar (1982) detected some pulses which were less evident than in females.

Secretory pulses have been recorded in female carp but have not yet been studied in males. It is not known if the GTH pulses are predeced by those of $\mathrm{GnRH}$ secretion but, in view of results in higher vertebrates, they are likely to be. 
It is also known that continuous $\mathrm{GnRH}$ administration by an implant, for example, sustains GTH secretion (Weil and Crim, 1983).

The low basal GTH levels found in males during spermatogenesis may be related with the nature of the hormone measured. The GTH mentioned is purified maturational (glycoprotein) GTH as far as its biological action on oocyte maturation and spermiation or on the final phase of gametogenesis is concerned. It may be that the more specific non-glycoprotein hormone of vitellogenesis (vitellus incorporation in females) postulated by Idler and $\mathrm{Ng}$ (1983) also occurs in males. However, the actual data available show that maturation GTH alone can at least restore the quality of spermatogenesis in hypophysectomized goldfish (45). This would indicate that a single gonadotropic hormone stimulates spermatogenesis. According to Fontaine (1984), there is only a single gonadotropic hormone in teleosts but another hormone like TSH might play a role. This would correspond to the survival of its double function (gonadotropic and thyreotropic) postulated by this author in agnaths. Experimental results tend to show that spermatogenesis in eel is thyreotropin-dependent (Khan, 1983 ; Leloup-Hatey, personal communication).

GTH requirements could vary at various times during spermatogenesis, depending on the complexity of this cycle, as do the number of spermatogonial generations and the degree of spermatid and sperm transformation. GTH is indispensable to spermatid elongation in guppy but does not appear necessary to the simplified spermiogenesis of goldfish. It should be noted that mammalian gonadotropic hormones have no effect on goldfish spermatogenesis. Specificity of zoological action also seems to be true within a class of fish. In contrast to mammals, this process might result from a wider species difference due to longer evolution of the species. Salmonids as cyprinids show several spermatogenetic waves so that several cell types are present in the testis at the same time; therefore it is difficult to relate a given hormone level to a cell type and to exactly deduce hormonal requirements at various spermatogenetic stages.

At the onset of and during spermiation, circulating levels of GTH and steroids are markedly higher than during spermatogenesis. In trout a temporary rise in GTH just before spermiation appears to initiate a rise in $11-\mathrm{KT}$, the latter remaining high throughout spermiation. Other steroid hormones such as $17 \alpha-$ $20 \beta$-dihydroxy-4-pregnen-3-one $(17 \alpha-20 \beta$-P) have been identified in trout plasma during this period (Scott and Baynes, 1982). It is possible that 11-KT could madoulate $17 \alpha-20 \beta$-P production (Leprêtre, personal communication) and that the latter could be directly involved in the process of spermiation, its role being limited to the secretion of seminal fluid and the control of its composition. Scott and Baynes (1982) reported a high correlation between $K^{+}$levels in the seminal fluid and circulating levels of $17 \alpha-20 \beta-P$. Moreover, progesterone stimulates spermiation in trout, goldfish and pike. Therefore, progesterone (rarely found in a male vertebrate) could be associated with spermiation, an original event in fish with lobular testes.

The arrest of spermiation coincides exactly with the clearance of plasma 11KT (41) but also probably with that of $17 \alpha-20 \beta-\mathrm{P}$ according to the data of Scott 
and Baynes (1982). This would tend to also confirm the role of these steroids in spermiation.

From this moment, residual spermatozoa are phagocytosed by either Sertoli cells, spermiduct cells or macrophages. The antigenic recognition of spermatozoa by Sertoli cells or spermiduct epithelial cells could be modified when these steroids are absent. The spermatozoa would be recognized as foreign cells and be phagocytosed, and the testis barrier would no longer be uniquely morphological but also cytophysiological.

Gonadotropins also show zoological specificity in the case of spermiation (4) but hormones like HCG that have no effect on spermatogenesis in goldfish strongly stimulate spermiation in that fish but not in carp.

Spermiation seems to be a complex stage in the male reproductive cycle which is modulated by widely diverse hormonal mechanisms and modes of secretion. Spermiation is also the key stage of reproduction, resulting in the release of good quality spermatozoa at the time the most favorable environmental conditions occur simultaneously.

It is therefore necessary to determine the main environmental factors that affect the processes of spermatogenesis and spermiation in various species or groups of species. Two general types of reproductive cycle can be identified with each action of specific environmental factors.

In salmonids gametogenesis mainly depends on the photoperiod, while spermiation, and especially embryogenesis, has strict thermal requirements ( $<12^{\circ}$ for embryogenesis). Thus, reproduction occurs after gametogenesis with no clear evident stimuli or homonal response inducing spermiation. It is surprising that these species reproduce in winter ; in fact, salmonids eggs are large (up to $1 \mathrm{~cm}$ in diameter) and are autonomous at least two months before the alevins can feed. The temperature regulates embryogenesis and delays the swimming up stage until food is available in the environment.

In cyprinids, gametogenesis and spermiation-ovulation may be dissociated (example: carp). Temperature is one of the major environmental factors, although the role of photoperiod has not been analysed in detail. Below certain thermic limits, gametogenesis is inhibited. As concerns spermiation, the temperature rise in spring, which fluctuates continuously, causes plasma GTH to increase and stimulates spermiation. Another social-type environmental factor is also evident via pheromones. The males seem to know the sexual state of the females and particularly when ovulation is initiated. In cyprinids the direct effect of temperature on spermiation and ovulation is an efficient way of obtaining egg laying at the time when food for the larvae is already present because the eggs of this species are small and hatch only several days after they are laid. A social stimulation coincides with the rise in temperature, leading to a rise in plasma GTH permitting a specific volume of sperm to be mobilized for fecundation 166 and Kyle and Stacey, personal communication). In this way, cyprinids, as carp and goldfish, can compensate for the absence of large sperm reserves in the spermiducts.

Another type of essential information in fish with external fecundation is that which induces the synchronous release of the sexual products at fertilization. The 
simultaneous release of spermatozoa and ova has a quasi-obligatory character due to the short life of the gametes once they are in contact with the water. Various hypotheses have been proposed. The stimuli causing synchronous release may be transmitted via the lateral line during spawning behavior; cutting the lateral streak in medaka suppresses oviposition. According to the pheromone hypothesis, the laying of the first eggs, accompanied by pheromone-type factors, would release an immediate ejaculation reflex. Demski and Hornby (1982) consider that this is possible and that the stimuli-response interval (contraction of the spermiduct and abdominal musculature) is very brief.

Species differences in spe ratogenetic production and spermiation yield are

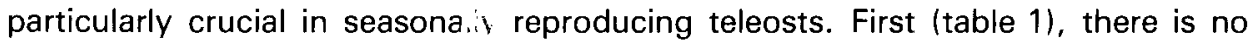
relationship between the male and female GSI. Neither is there any between female fecundity (number of ova laid per $\mathrm{g}$ of liveweight) and spermatogenetic production, i.e. the ratio of spermatozoa produced/ovum, does not tend to be constant. On the contrary, the process is amplified with 3.6 billion spermatozoa per ovum in trout. Estimating the real number of spermatozoa released by using the coefficient of spermiation yield to express spermatogenetic production instead of the number of spermatozoa produced in the testis does not change the basic differences.

Sperm motility is very short in freshwater species with external fecundation (30 to $60 \mathrm{sec}$ in salmonids and cyprinids). It is slightly longer in saltwater fish, being $2 \mathrm{~min}$ in sea-bass gilthead sea-bream and reaching several hours in herrings (Dushkina, 1973). Trout spermatozoa rapidly become immotile when the level of ATP drops, indicating that dynein ATPase activity is higher than mitochondrial synthetase activity. The low levels of internal ATP could inactivate the membrane pump and phosphorylation implicated in flagellar beating; this inactivation is irreversible because motility is not re-initiated when the ATP level rises. Inhibition of motility by $\mathrm{KCl}$ or by acid $\mathrm{pH}$ is apparently not due to a simple acidification of the internal medium as in sea-urchin (Christen et al,, 1982). The process of membrane permeability are probably necessary to the regulation of motility ; present studies emphasize membrane potential and $\mathrm{Ca}^{++}$movement.

Sperm aging in trout is expressed by a decrease in cyclic AMP (Benau and Terner, 1980) and we have observed that cAMP had to be added into the reactivation medium to activate demembranated spermatozoa near the end of spermiation. These aging processes, causing a change in sperm quality, probably occur in other species such as carp and pike in which spermatogenesis and spermiation are dissociated, but this point still has to be studied.

The number of spermatozoa also appears to compensate for short motility time, as seen in trout, but these data cannot be applied to pike and carp since motility time is shorter in pike which produces fewer spermatozoa. Egg diameter is also a factor since in order to be fertilized a large egg (compared to a small egg) requires more spermatozoa having the same motility time or longer. This argument has been shown in salmonids, the high number of spermatozoa compensating for the short motility time and the large egg diameter, but it cannot be applied to pike which have relatively large eggs, short motility and a small number of spermatozoa. 
Another factor could be differences in sexual behavior. The two species in this study which have the highest spermatogenetic production and the highest gonadal weight, carp and trout, are polyandrous (4-6 males/female), while pike is not (1-3 males/female) and tilapia spawns in couples.

Carp and trout males participate more often in reproduction and release more sperm than pike and tilapia. Much has been written on salmonids ; several large males participate in the ferlitization of one female with chances of fecundation which vary depending on their position in the social system lexample : coho saimon), but all the males release sperm (Gross, 1984).

Small, precocious males, not included in the social system of the large males because they are not dominated due to their small size and lack of color, actively participate in reproduction with the same chances of success as the dominant males (Gross, 1984). These precocious males might be important in the sense that they contribute to mix sperm from several males at reproduction.

The testicular weight of primates has been related with the mode of reproduction, polygamous species having a higher testicular weight than species in which the female mates with only one male (Harcourt et al., 1981 ; Harvey and Harcourt, 1982). This hypothesis might also be valid for fish, i.e. testicular weight, which shows higher variations than in mammals, and spermatogenetic production might be related with the mode of reproduction, whether isolated or in groups. Tilapia which mate in couples have a low testicular weight : $0.4-2 \%$ of body weight (Peters, 1971). Peters has shown a relationship between the lower GSI and the smaller number of eggs laid but noted that testicular weight did not vary before or after spawning; this author concluded that the quantity of sperm released must be extremely low and mentioned that for insemination to be efficient, the spermatozoa must be released very close to the eggs. Leporinus scrofa, a South American species, also has a very low GSI $(0.2 \%$ ) (Godinho, personal communication), but its mode of reproduction is not known.

Large volumes of sperm are released during spawning in carp and trout, making the medium opaque (Breder and Rosen, 1966). These amounts of sperm are mobilized in very different ways in the two species. In trout, the spermatozoa accumulate in the spermiducts from the onset of spermiation, while in carp the spermatozoa are only mobilized a few hours before spawning. The males seem to know the physiological state of the females; giving an injection of gonadotropic hormone to female carp or HCG to female goldfish stimulates spermiation within a few hours via a rise in gonadotropin (Kyle and Stacey, personal communication). The males must perceive a preovulatory peak and mobilize sperm that accumulates in the genital tract, probably in the system of lacunae that constitute the intratesticular "spermiduct " because the free spermiduct is not very developed in carp, and spermiation may continue throughout spawning. The mode of communication is not known; it may be accomplished by sexual pheromones such as glucuronides which are released by the females and induce mating behavior in Brachydanio and gobies (Van den Hurk and Lambert, 1983; Colombo et al., 1982).

The amount of sperm released would ensure a sufficient sperm/egg ratio in 
species such as salmonids which reproduce in running water or in carp which stir up the water by rapid swimming, causing the sperm to be quickly diluted. However, seminal fluid, as ovarian fluid, might create a favorable microenvironment for fertilization by limiting hypo-osmotic shock or by maintaining a favorable $\mathrm{pH}$ for fecundation. This would explain why salmonids reproduce in water of low alkalinity or at $\mathrm{pH}$ of less than 7, although it is known that at this $\mathrm{pH}$ the spermatozoa are not motile.

The method used to measure the amount of spermatozoa released by trout throughout spermiation leads to an overestimate of the number actually available for fecundation. The values measured correspond to a production of several weeks, or even several months, in pisciculture conditions, while in nature the period during which the females ovulate is extremely limited. Deroche (1969) studying lake trout, reported a case in which the total length of the spawning period was 18 days but noted that most of the females reproduced during only two nights. Strictly speaking, the spawning period is usually shorter in salmonids than the period during which the males spermiate. Spermiation begins shortly before the females ovulate (in a same population). It is therefore not surprising that the sperm accumulates beforehand in the spermiducts of the male. Female carp have a longer spawning period (several months) and it depends a great deal on the temperature. The strategy of the male carp is different; there is no preaccumulation of sperm in the genital tract (where the sperm may age), but there is preovulatory mobilization which can be explained by the longer spawning period that depends directly on environmental factors. This is also related with the fact that carp testicular spermatozoa mobilized experimentally throughout the year by hormonal stimulation retain their fertilizing ability, while good quality trout spermatozoa are available for only several months.

\section{Conclusion.}

Some conclusions and hypotheses have been put forward concerning the reproductive function in several groups of teleost fish, and we have tried to define the significance of various modes of reproduction.

Two large groups can be distinguished by their physiology (internal and external fecundation, sperm biology), morphology (structure of the testis and spermatozoon) and biochemical characteristics (transformation of nuclear protein, presence or absence of sperm energy stores) (fig. 14).

The first group includes species such as guppy with tubular testes and internal fecundation. The spermatozoa have an elongated head but no glycogen stores and remain motile for several hours. They are usually associated in spermatozeugmas, thus facilitating transfer to the female genital tract. Transfer occurs through the anal fin that is transformed into a gonopod. In some species the spermatozoa remain free and are transferred by the gonopod in the form of a pseudopenis.

The second group of fish includes those with lobular testes and external fecundation. Sperm morphology is simple since there is no mid-piece or large 
energy stores, and motility is short. The spermatozoa are very vulnerable in fresh water where they undergo severe hypo-osmotic shock, including rupture of the plasma membrane. They are "saved " by the rapidity with which they penetrate the egg. The spermatozoon seeks protection in a structure which resists hypotonicity due to the cortical reaction and the resulting impermeability. Therefore this structure only remains open for several minutes. The short life of the spermatozoon is thus related with the short time the eggs are fertilizable once they are in fresh water.

In spite of the fact that internal fecundation protects the gametes, it is not more economical in terms of sperm than external fecundation ; sperm production in guppy (which has internal fecundation) is higher than in pike which has external fertilization. Moreover, species with tubular testes have an original mode of internal fecundation which is found only in teleosts but not in higher vertebrates. However, some structural elements prefiguring the testicular organization of higher vertebrates occur in lobular testes.

Tubular type
(guppy)
Relationships
Spermatids -
Sertoli cells

FIG. 14. - Some characteristics of male reproduction in species with tubular (guppy) and lobular (salmonids, cyprinids) testes. 
The wide differences in spermatogenetic production occurring among species have no satisfactory answer, if only the physiological parameters are considered ; there is no relationship between spermatogenetic production and spermiation yield, between the number of spermatozoa produced or released and female fecundity or egg diameter. However, there is a behavioral relationship, species with a high GSI spawning in a group and those with a low GSI spawning in couples. The number of spermatozoa needed for fertilization is higher in the former than in the latter, the males participating more often in reproduction. The large volumes of sperm released in group spawning might create a favorable microenvironment for fertilization.

Spermatogenesis and spermiation, the major events of the annual cycle, have very different time lengths, the first being shorter than the second; they also occur at different seasons. Both are continuous in trout and tench but they are separated by a resting period in winter in carp and pike. In roach, even spermatogenesis is inhibited in winter. The differences found between the seasons of spermiation may be related with species ecological requirements. The large eggs of salmonids (autumn and winter spawning) have a 2 to 3-month autonomy between reproduction and the trophic life of the juveniles that occurs at the end of winter or in spring. On the contrary, the small eggs of cyprinids have very little autonomy (not more than several days) between hatching and first food intake. Cyprinids reproduce at a time when food is already found in the medium or there are indications that it soon will be. The temperature rise in the spring seems to be a logical reference for spermiation and ovulation. Spermatogenesis in pike and carp in spring and autum occurs separately from spermiation, while spermatogenesis in tench begins at the end of winter and is rapidly followed by spermiation.

It is probable that various environmental factors play a role in the regulation of spermatogenesis and spermiation. Spermatogenesis depends more on wide, long-term variations such as seasonal changes in daylength and temperature. Spermiation is more directly influenced by short-term variations causing an immediate response, such as exceeding the critical thermic threshold or the appearance of environmental (laying substrates) or social (presence of females ready to ovulate) stimuli.

The intensity of spermiation in salmonids depends on the presence of females and on low temperatures, the optimum $\left(<12-13^{\circ} \mathrm{C}\right)$ corresponding to the thermic requirements for incubation. Spermiation is arrested at $18{ }^{\circ} \mathrm{C}$ in trout in spite of a high level of GTH ; this may be due to the inactivation of androgens converted into conjugates and glucuronides (Kime, 1979) and would be a way of regulating spermiation by inhibiting it when thermic conditions do not favor egg survival.

In cyprinids, various regularoty mechanisms are superimposed that lead to spermiation and sperm release. As favorable environmental conditions (particularly thermic conditions) may occur late, the brood fish can remain in a holding state which does not affect sperm survival. In carp and goldsfish, which have no storage structures and whose spermatozoa are vulnerable when released 
into the spermiduct, the male mobilizes large volumes of sperm only a few hours before spawning. In this case, the female gives a social signal probably in response to the environment (heat fluctuations, presence of water plants). Thus, spermiation requires two distinct conditions : the temperature that is facilitating and must reach an optimal level and social stimulus that is determinant.

Why are the meeting of the sexes and of the gametes and the development of the resulting eggs and larvae guaranteed by such diverse modes of reproduction, morphological structures and regulatory mechanisms? Teleosts include more than 20000 species and thus constitute the largest, and probably the most diversified an oldest, group of vertebrates. On the other hand, aquatic media are extremely varied. Therefore, it may be that fish, by a sort of adaptive dialogue with the environment during their long history, have managed to colonize a very wide variety of biotopes. The diversification in modes of reproduction in the large teleost group would be a response to the diverse environments.

Reçu en juillet 1985.

Accepté en mai 1986.

\section{Résumé. Spermatogenèse et spermiogenèse chez des Poissons Téléostéens.}

L'ensemble des processus qui concourent à la formation des spermatozoïdes, à leur libération et à la fécondation apparaissent extrêmement diversifiés chez les poissons Téléostéens.

On identifie d'abord deux grands types de structure testiculaire, tubulaire et lobulaire, ce dernier présentant lui-même une grande diversité dans l'organisation des lobules et la structure des conduits génitaux.

- La spermatogenèse peut revêtir un aspect continu (guppy) ou discontinu avec des cycles qui s'interpénètrent (carpe) ou sont bien séparés dans le temps (truite).

- La spermiogenèse présente des degrés de complexification croissants conduisant à la formation de spermatozoïdes extrêmement simplifiés, comme ceux de la carpe (tête sphérique, transformation très sommaire des histones nucléaires, pièce intermédiaire très simplifiée avec restes de cytoplasme et mitochondries non transformées) ou beaucoup plus complexes comme ceux du guppy (allongement de la tête spermatique, transformation histones-protamines, transformation du complexe centriole inséré dans une profonde encoche nucléaire, pièce intermédiaire très développée comportant des réserves de glycogène). - La production spermatogénétique est extrêmement variable (RGS variant entre 0,2 et $10 \%$ et production annuelle comprise entre 100 et $700010^{6}$ spermatozoïdes $/ \mathrm{g}$ de poids corporel).

- Le rendement de la spermiation varie fortement entre espèces, mais aussi à l'intérieur d'une même espèce (20 à $90 \%$ chez la truite).

- Le modèle endocrinien de la spermatogenèse et de la spermiation est très différent chez la carpe et la truite. Les facteurs de l'environnement prépondérants sont la photopériode chez la truite et la température chez la carpe pour la spermatogenèse, la température chez la truite à laquelle s'ajoute l'environnement social chez la carpe pour la spermiation.

- La physiologie du sperme (durée de survie in vivo et in vitro, durée de motilité, métabolisme) est très différente dans les quelques espèces étudiées.

De cet ensemble de caractéristiques on peut identifier deux groupes qui sont fondamentalement différents tant sur le plan physiologique (fécondation interne ou externe, physiologie du sperme) que morphologique (structure du testicule et du spermatozoïde). II s'agit du groupe de Athériniformes (type guppy à testicule tubulaire) et du groupe des autres Téléostéens à reproduction saisonnière à testicule lobulaire. 


\section{I. - Author's references called in text by number}

(1) BILLARD R., 1969. La spermatogenèse de Poecilia reticulata. I. Estimation du nombre de générations goniales et rendement de la spermatogenèse. Ann. Biol. anim. Bioch. Biophys., 9. 251-271.

(2) EILLARD R., FLÉCHON J.-E., 1969. Spermatogonies et spermatocytes flagellés chez Poecilia reticulata (Téléostéen cyprinodontiforme). Ann. Biol. anim. Bioch. Biophys., 9, 281286.

(3) BILLARD R, 1984. Ultrastructural changes in the spermatogonia and spermatocytes of Poecilia reticulata during spermatogenesis. Cell Tissue Res., 237, 219-226.

(4) BILLARD R., FOSTIER A., WEIL C., BRETON B., 1982. Endocrine control of spermatogenesis in teleost fish. Can. J. Fish. Aquat. Sci., 39, 65-79.

(5) BILLARD R., JALABERT B., 1972. Les cellules de Sertoli des poissons Téléostéens. I. Etude ultrastructurale. Ann. Biol. anim. Bioch. Biophys., 12, 19-32.

(6) BILLARD R., MEUSY-DESSOLLES N., FLECHON J.-E., 1971. Les cellules interstitielles de quelques poissons Téléostéens (abstr.). J. Microscopie, 11, 30.

(7) BILLARD D., TAKASHIMA F., 1983. Resorption of spermatozoa in the sperm duct of rainbow trout during the post-spawning period. Bull. jap. Soc. Sci. Fish, 49, 387-392.

(8) BILLARD R., 1970. La spermatogenèse de Poecilia reticulata. III. Ultrastructure des cellules de Sertoli. Ann. Biol. anim. Bioch. Biophys., 10, 37-50.

(9) LEBRUN C., BILLARD R., JALABERT B., 1982. Changes in the number of germ cells in the gonads of the rainbow trout (Salmo gairdneri) during the first 10 post-hatching weeks. Reprod. Nutr. Dévelop., 22, 405-412.

(10) BILLARD R., 1970. La spermatogenèse de Poecilia reticulata. IV. La spermiogenèse. Etude ultrastructurale. Ann. Biol. anim. Bioch. Biophys., 10, 493-510.

(11) PICHERAL B., BILLARD R., BASSEZ Th., 1972. Localisation des protamides dans le noyau des spermatides du Téléostéen Poecilia reticulata. Etude autoradiographique (abstr.). J. Microscopie, 14, 80-81.

(12) BILLARD R., JALABERT B., 1973. Le glycogène au cours de la formation des spermatozoïdes et de leur transit dans le tractus génital femelle chez le Guppy (Poisson Poecilidae). Ann. Biol. anim. Bioch. Biophys., 13, 313-320.

(13) BILLARD R., 1983. Spermiogenesis in the rainbow trout (Salmo gairdneri). An ultrastructural study. Cell Tissue Res., 233, 265-284.

(14) BILLARD R., 1969. Ultrastructure comparée de spermatozoïdes de quelques poissons Téléostéens. Quaderno, N. 137, 71-79, Baccetti Edit.

(15) BILLARD R., 1983. Ultrastructure of trout spermatozoa : changes after dilution and deepfreezing. Cell Tissue Res., 228, 205-218.

(16) MATTEI C., MATTEI X., MARCHAND B., BILLARD R., 1981. Réinvestigation de la structure des flagelles spermatiques. Cas particulier des spermatozoïdes a mitochondrie annulaire. $J$. Ultrastruct. Res., 74, 307-312.

(17) BILLARD R., GINSBURG A. S., 1973. La spermiogenèse et le spermatozoïde d'Anguilla anguilla L. Ann. Biol. anim. Bioch. Biophys., 13, 523-534.

(18) BILLARD R., 1968. Influence de la température sur la durée et l'efficacité de la spermatogenèse de Guppy Poecilia reticulata. C.R. Acad. Sci. Paris, Sér. D, 266, 2287-2290.

(19) BILLARD R., 1969. La spermatogenèse de Poecilia reticulata. II. La production spermatogénétique. Ann. Biol. anim. Bioch. Biophys., 9, 307-313.

(20) BILLARD R., SOLARI A., ESCAFFRE A. M., 1974. Sur une méthode d'analyse quantitative de la spermatogenèse des Téléostéens. Ann. Biol. anim. Bioch. Biophys., 14, 87-104.

(21) BILLARD R., 1983. A quantitative analysis of spermatogenesis in the trout Salmo trutta fario. Cell Tissue Res., 230, 495-502.

(22) BILLARD R., ESCAFFRE A.-M., 1975. Identification des stades de la spermatogenèse de la truite fario d'après la morphologie des gonades et la spermiation. Bull. Fr. Pisci., 256, 111 113. 
(23) BILLARD R., BRETON B., JALABERT B., 1971. La production spermatogénétique chez la truite. Ann. Biol. anim. Bioch. Biophys., 11, 190-212.

(24) BILLARD R., 1986. Gametogenesis in the brown trout (Salmo trutta fario) bred in captivity: a quantitative study (in preparation).

(25) BILLARD R., BRETON B., FOSTIER A., JALABERT B., WEIL C., 1978. Endocrine control of the teleost reproductive cycle and its relation to external factors : Salmonid and Cyprinid models. In : Comparative endocrinology, GAILLARD P. J. and BOER H. H. Eds., Elsevier. North Holland, Biochem. Press, Amsterdam, 37-48.

(26) ESCAFFRE A.-M., BILLARD R., 1976. Le cycle spermatogénétique du gardon Rutilus rutilus. Cahiers Lab. Montereau, 3, 43-46.

(27) BRETON B., HOROSZEWICZ L., BILLARD R., BIENIARZ K., 1980. Temperature and reproduction in tench, effect or a rise in the annual temperature regime on gonadotropin, level gametogenesis and spawning. I. Case in the male. Reprod. Nutr. Dévelop., 20, 105-118.

(28) BILLARD R., MACKAY W. C., MARCEL J., 1983. Evolution de la gamétogenèse, du poids du corps et des gonades au cours du cycle reproducteur du brochet. (Esox lucius), 53-61. In : R. BILLARD Le Brochet, gestion dans le milieu naturel et élevage, INRA Publ., Paris.

(29) BILLARD R., 1981. The reproductive cycle in teleost fish. Riv. it. Pisci. Ittiop., A.XVI, 79-80, 106-118.

(30) BILLARD R., 1974. La production spermatogénétique de la truite arc-en-ciel au cours du premier cycle reproducteur. Bull. fr. Pisci, 253, 139-149.

(31) BOURLIER A., BILLARD R., 1984. Delayed gametogenesis and spawning in rainbow trout (Salmo gairdneri) kept under permanent light during the first and second reproductive cycles. Aquaculture, 43, 259-268.

(32) DE MONTALEMBERT G., MARCEL J., BILLARD R., 1980. La spermiation chez le brochet. I. Evolution de la quantité de sperme récolté au cours de la saison de reproduction. Bull. fr. Pisci, 276, 90-103.

(33) TAKASHIMA F., WEIL C., BILLARD R., CRIM L. W., FOSTIER A., 1984. Acceleration of spermiation in carp by LH-RH analogue. Bull. jap. Soc. Sci. Fish., 50, 1323-1329.

(34) BRETON B., KANN G., BURZAWA-GÉRARD E., BILLARD R., 1971. Dosage radioimmunologique d'une hormone gonadotrope de carpe Cyprinus carpio. C.R. Acad. Sci., Paris, Sér. D, 272, 1515-1517.

(35) JALABERT B., BRETON B., BILLARD R., 1974. Dosage biologique des hormones gonadotropes de poissons par le test de maturation in vivo des ovocytes de truite. Ann. Biol. anim. Bioch. Biophys., 14, 217-228.

(36) FOSTIER A., BILLARD R., BRETON B., LEGENDRE M., MARLOT S., 1982. Plasma 11-oxotestosterone and gonadotropin during the beginning of spermiation in rainbow trout / $\mathrm{Salmo}$ gairdneri R.) Gen. comp. Endocrinol., 46, 428-434.

(37) BILLARD R., BRETON B., DUBOIS M. P., 1971. Immunocytologie et histochimie des cellules gonadotropes et thyréotropes hypophysaires chez la carpe Cyprinus carpio. C.R. Acad. Sci., Paris, Serr. D, 272, 981-983.

(38) JALABERT B., BILLARD R., 1968. Hypophysectomie de Poecilia reticulata (Poisson Téléostéen). Ann. Biol. anim. Bioch. Biophys., 8, 99-105.

(39) BILLARD R., RICHARD M., BRETON B., 1976. Stimulation of gonadotropin secretion after castration in rainbow trout. Gen. comp. Endocrinol., 33, 163-165 et C.R. Acad. Sci., Paris, Sér. D, 283, 171-174.

(40) BILLARD R., PETER R. E., 1982. A stereotaxic atlas and technique for nuclei of the diencephalon of rainbow trout (Salmo gairdneri). Reprod. Nutr. Dévelop., 22, 1-25.

(41) FOSTIER A., BILLARD R., BRETON B., 1984. Plasma 11-oxotestosterone and gonadotropin in relation to the arrest of spermiation in rainbow trout (Salmo gairdneri). Gen. comp. Endocrinol., 54, 378-381.

(42) BILLARD R., 1969. Hypophysectomie et spermatogenèse chez Poecilia reticulata (Poisson Cyprinodontidae). C.R. Acad. Sci., Paris, Sér. D, 268, 1856-1859.

(43) BILLARD R., BRETON B., JALABERT B., 1970. Inhibition de la spermatogenèse de Guppy (Poisson Cyprinodontidae) par le méthallibure. Ann. Biol. anim. Bioch. Biophys., 10, 511-515. 
(44) BRETON B., BILLARD R., JALABERT B., 1973. Spécificité d'action et relations immunologiques des hormones gonadotropes de quelques Téléostéens. Ann. Biol. anim. Bioch. Biophys., 13, 347-362.

(45) BILLARD R., 1974. Testosterone : effects on the maintenance of spermatogenesis in intact and hypophysectomized goldfish Carassius auratus. I.R.C.S., 2, 1231.

(46) BRETON B., JALABERT B., BILLARD R., 1973. Pituitary and plasma gonadotrophin levels and spermatogenesis in the goldfish Carassius auratus after methallibure treatment. $J$. Endocr., 59, 415-420.

(47) BILLARD R., BRETON B., ESCAFFRE A.-M., 1971. Maintien et restauration de la spermatogenèse par un extrait acétonique hypophysaire de Carpe chez le Cyprin (Carassius auratus) traité au méthallibure. Ann. Biol. anim. Bioch. Biophys., 11, 167-174.

(48) BILLARD R., ESCAFFRE A.-M., 1973. Effects of HCG and carp gonadotropin on the maintenance of spermatogenesis in hypophysectomized goldfish Carassius auratus. I.R.C.S., (73-12), 15-1-20.

(49) BILLARD R., BURZAWA-GÉRARD E., BRETON B., 1970. Régénération de la spermatogenèse du Cyprin hypophysectomisé Carassius auratus L. par un facteur gonadotrope hautement purifié de carpe. C.R. Acad. Sci., Paris, Sér. D, 271, 1896-1899.

(50) BILLARD R., 1977. Effect of various hormones on sperm release in the hypophysectomized goldfish. I.R.C.S., 5, 188.

(51) BILLARD R., 1976. Induction of sperm release in the goldfish by some steroids. I.R.C.S., $4,42$.

(52) BRETON B., BILLARD R., JALABERT B., KANN G., 1972. Dosage radioimmunologique des gonadotropines plasmatiques chez Carassius auratus au cours du nycthémère et pendant I'ovulation. Gen. comp. Endocrinol., 18, 463-468.

(53) BILLARD R., MARCEL J., 1980. Stimulation of spermiation and induction of ovulation in Northern pike (Esox lucius). Aquaculture, 21, 181-195.

(54) DE MONTALEMBERT G., BRY C., BILLARD R., 1978. Control of reproduction in Northern pike (Esox lucius). Trans. amer. Fish. Soc., Special Publ., 11, 217-225.

(55) BILLARD R., 1978. Testicular feed back on the hypothalamo-pituitary axis in rainbow trout (Salmo gairdneri). Ann. Biol. anim. Bioch. Biophys., 18, 813-818.

(56) BRETON B., BILLARD R., 1980. Mise en évidence d'une régulation non-stéroïdienne d'origine testiculaire sur la sécrétion d'hormone gonadotrope (GTH) chez la truite arc-en-ciel. C. $R$. Acad. Sci., Paris, 290, 1091-1094.

(57) BILLARD R., 1982. Attempts to inhibit testicular growth in rainbow trout with antiandrogens (Cyproterone, cyproterone acetate, oxymetholone) and Busulfan given during the period of spermatogenesis. Gen. comp. Endocrinol., 48, 33-38.

(58) CRIM L. W., BILLARD R., GENGE P. D., IDLER D. R., 1982. The influence of immature gonads on onset of gonadotropic hormone accumulation in the juvenile rainbow trout pituitary gland. Gen. comp. Endocrinol., 32, 213-220.

(59) CRIM L. W., PETER R. E., BILLARD R., 1981. Onset of gonadotropic hormone accumulation in the immature trout pituitary gland in response to estrogen or aromatizable androgen steroid hormones. Gen. comp. Endocrinol., 44, 374-381.

(60) BILLARD R., PETER R. E., 1977. Gonadotropin release after implantation of antiestrogens in pituitary and hypothalamus of goldfish Carassius auratus. Gen. comp. Endocrinol., 32, 213220.

(61) BILLARD R., CRIM L. W., PETER R. E., BRETON B., 1982. Long-term changes in plasma and pituitary GTH after castration of rainbow trout at an immature stage, 50 . In C. J. J. RICHTER and H. J. Th. GOOS. Reproductive physiology of fish. PUDOC Wageningen.

(62) DUBOIS M. P., BILLARD R., BRETON B., 1978. Use of immunofluorescence for localisation of somatostatin-like antigen in the rainbow trout (Sa/mo gairdneri). Comparative distribution of LHRH and neurophysin. Ann. Biol. anim. Bioch. Biophys., 18, 843-850.

DUBOIS M. P., BILLARD R., BRETON B., PETER R. E., 1979. Comparative distribution of somatostatin LH-RH neurophysin, and $\alpha$-endorphin in rainbow trout : an immunocytological study. Gen. comp. Endocrinol., 37, 220-232. 
(63) GILLET C., BILLARD R., BRETON B., 1977. Effets de la température sur le taux de gonadotropine plasmatique et la spermatogenèse du poisson rouge Carassius auratus. Can. J. Zool., 55. 242-245.

GILLET C., BILLARD R., 1977. Stimulation of gonadotropin secretion in goldfish by elevation of rearing temperature. Ann. Biol. anim. Bioch. Biophys., 17, 673-678.

(64) GILLET C., BILLARD R., BRETON B., 1981. La reproduction du poisson rouge Carassius auratus élevé à $30^{\circ} \mathrm{C}$. Effet de la photopériode, de l'alimentation et de l'oxygénation. Cahiers Lab. Montereau, 11, 49-56.

(65) GILLET C., BILLARD R., BRETON B., 1977. Influence de la température sur la reproduction du poisson rouge (Carassius auratus L.). Cahiers Lab. Montereau, 5, 25-42.

GILLET C., BILLARD R., 1981. Effets de la température, de la photopériode et niveaux alimentaires sur la gonadotropine plasmatique et hypophysaire et la gamétogenèse du Poisson rouge. Cahiers Lab. Montereau, 11, 41-48.

(66) KYLE A. L., STACEY N. E., PETER R. E., BILLARD R., 1984. Elevations in gonadotropin concentrations and milt volumes as a result of spawning behavior in the goldfish. Gen. comp. Endocrinol., 57, 10-22.

(67) BILLARD R., BRETON B., 1977. Sensibilité à la température des différentes étapes de la reproduction chez la truite arc-en-ciel. Cahiers Lab. Montereau, 5, 5-24.

(68) BRETON B., BILLARD R., 1977. Effects of photoperiod and temperature on plasma gonadotropin and spermatogenesis in the rainbow trout Salmo gairdneri Richardson. Ann. Biol. anim. Bioch. Biophys., 17, 331-340.

(69) BILLARD R., REINAUD P., LE BRENN P., 1981. Effects of changes of a photoperiod on gametogenesis in the rainbow trout (Salmo gairdneri). Reprod. Nutr. Dévelop., 21, 1009-1014.

(70) MAGRI M. H., BILLARD R., REINAUD P., FOSTIER A., 1981. Induction of gametogenesis in the juvenile rainbow trout. Gen. comp. Endocrinol., 46, 394 (Abstr. 141).

(71) JALABERT B., BILLARD R., CHEVASSUS B., 1975. Preliminary on sex control in trout : production of sterile fishes and stimultaneous self-fertilizable hermaphrodites. Ann. Biol. anim. Bioch. Biophys., 15, 19-28.

(72) BILLARD R., RICHARD M., ROMBAUTS P., 1982. Inhibition of spermatogenesis and vitellogenesis in rainbow trout by hormonal additives (estradiol and methyltestosterone) included in the diet. Progr. Fish Cult., 44, 15-18.

(73) BILLARD R., BRETON B., RICHARD M., 1981. On the inhibitory effects of some steroids on spermatogenesis in adult rainbow trout (Salmo gairdneri). Can. J. Zool., 59, 1479-1487.

(74) BILLARD R., ALAGARSWAMI K., PETER R. E., BRETON B., 1983. Potentialisation par le pimozide des effets du LHRH-A sur la sécrétion gonadotrope hypophysaire, l'ovulation et la spermiation chez la carpe commune (Cyprinus carpio). C. R. Acad. Sci, Paris, Sér. D, 296, 181-184.

(75) BILLARD R., CHOISIS J. P., REINAUD P., 1983. Stimulation of spermiation in carp in response to LHRH and D-ALA6-LHRH éthylamide. Aquaculture, 35, 173-176.

(76) SANCHEZ-RODRIGUEZ M., BILLARD R., 1977. Conservation de la motilité et du pouvoir fécondant du sperme de la truite arc-en-ciel maintenu à des températures voisines de $0^{\circ} \mathrm{C}$. Bull. fr. Pisci., 265, 144-152.

(77) BERGE P., VOlOCHINE B., BILLARD R., HAMELIN A., 1967. Mise en évidence du mouvement propre de microorganismes vivants grâce à l'étude de la diffusion inélastique de la lumière. C. R. Acad. Sci., Paris, Sér. D., 265, 889-892.

(78) BILLARD R., 1978. Changes in structure and fertilizing ability of marine and freshwater fish spermatozoa diluted in media of various salinities. Aquaculture, 14, 187-198.

(79) BILLARD R., BRETON B., 1970. Modifications ultrastructurales et cytochimiques de spermatozoïdes après dilution, chez les Poissons d'eau douce. Soc. fse. Microsc. électron. VII' Congr. intern. Microsc. électron., Grenoble 1970, 637-638.

(80) BILLARD R., BRETON B., 1976. Sur quelques problèmes de physiologie du sperme, chez les poissons Téléostéens. Rev. Trav. Inst. Pêches Marit., 40, 501-503.

(81) LEGENDRE M., BILLARD R., 1980. Cryopreservation of rainbow trout sperm by deepfreezing. Reprod. Nutr. Dévelop., 20, 1859-1868. 
(82) BILLARD R., 1976. Variation de la qualité des gamètes à différents niveaux du tractus génital chez la truite arc-en-ciel. Ann. Hydrobiol., 7, 97-104.

(83) BILLARD R., DUPONT J., BARNABÉ G., 1977. Diminution de la motilité et de la durée de conservation du sperme de Dicentrarchus labrax (poisson Téléostéen) pendant la période de spermiation. Aquaculture, 11, 363-367.

(84) BILLARD R., 1984. La conservation des gamètes et l'insémination artificielle chez le bar et la daurade. In G. BARNABÉ et R. BILLARD, L'Aquaculture du bar et des sparidés, I.N.R.A. Publ., Paris.

(85) BILLARD R., 1982. L'importance des protéines du liquide coélomique sur la fertilité des gamètes chez la truite arc-en-ciel et possibilité de substitution. Bull. fr. Pisci., 284, 168-177.

(86) BILLARD R., 1983. Effects of coelomic and seminal fluids and various saline diluents on the fertilizing ability of spermatozoa in the rainbow trout Salmo gairdneri. J. Reprod. Fert., 68 , 77-84.

(87) BILLARD R., 1981. Les effets du lavage des gamètes sur leur aptitude à la fécondation chez la truite arc-en-ciel. Rev. can. Biol., 40, 317-321.

(88) BILLARD R., JALABERT B., 1974. L'insémination artificielle de la truite Salmo gairdneri Richardson. II. Comparaison des effets des différents dilueurs sur la conservation de la fertilité des gamètes avant et après insémination. Ann. Biol. anim. Bioch. Biophys., 14, 601610.

(89) BILLARD R., MÉNÉZO Y., 1984. The amino-acid composition of rainbow trout seminal fluid blood plasma : a comparison with carp. Aquaculture, 41, 255-258.

(90) PLOUIDY M. G., BILLARD R., 1982. The chemical composition of the companion fluids of the gametes in the common carp (Cyprinus carpio L.), 134. In C. J. J. RICHTER and H. J. Th. GOOS, Reproductive physiology of fish. PUDOC Wageningen.

(91) MÉNÉZO Y., PLOUIDY M. G., BILLARD R., 1983. Sur la composition en acides aminés libres et peptidiques du liquide séminal de Carpe (Cyprinus carpio L.). C. R. Acad. Sci. Paris, série III, 296, 67-70.

(92) BILLARD R., 1981. Short-term preservation of sperm under oxygen atmosphere in rainbow trout (Salmo gairdneri). Aquaculture, 23, 287-293.

(93) BILLARD R., LEGENDRE M., 1982. Conservation à court terme des gamètes de truite arcen-ciel en condition in vitro sous atmosphère d'oxygène. Bull. fr. Pisci., 284, 162-167.

(94) MATEI D., MARCEL J., BILLARD R., 1980. Survie des gamètes en conditions in vitro et post mortem chez la truite arc-en-ciel. Bull. Acad. Sci. Agr. For. Roum., 10, 211-217.

(95) BILLARD R., MARCEL J., MATEI D., 1980. Survie post mortem des gamètes de truite fario, Salmo trutta fario. Can. J. Zool., 52, 29-33.

(96) PETIT J., JALABERT B., CHEVASSUS B., BILLARD R., 1973. L'insémination artificielle de la Truite. I. Effets du taux de dilution du $\mathrm{pH}$ et de la pression osmotique du dilueur sur la fécondation. Ann. Hydrobiol., 4, 201-210.

(97) BILLARD R., PETIT J., JALABERT B., SZÖLLÖSI D., 1974. Artificial insemination in trout using a sperm diluant, 715-723. In The early life history fish, J. H. S. BLAXTER, Edit. Springer Verlág, Berlin, Heidelberg, New York.

(98) BILLARD R., JALABERT B., BRETON B., 1974. L'insémination artificielle de la truite Salmo gairdneri Richardson. III. Définition de la nature et de la molarité du tampon à employer avec les dilueurs d'insémination et de conservation. Ann. Biol. anim. Bioch. Biophys., 14, 611-621.

(99) BILLARD R., GILLET C., 1975. Effets de la température sur la fécondation et la survie des gamètes chez la truite arc-en-ciel Salmo gairdneri. Bull. fr. Pisci., 259, 53-65.

(100) BILLARD R., CAZIN J. C., DEQUIDT J., ERB F., COLEIN P., 1978. Toxicité du Pyralène 3010 sur les ovules et les spermatozoïdes de truite arc-en-ciel avant et pendant l'insémination. Bull. fr. Pisci., 270, 238-249.

(101) BILLARD R., GILLET C., 1981. Vieillissement des ovules et potentialisation par la température des effets des micropolluants du milieu aqueux sur les gamètes chez la truite. Cahiers Lab. Montereau, 12, 35-42.

(102) BILLARD R., ROUBAUD P., 1984. The effect of metals and cyanide ions on fertilization in rainbow trout (Salmo gairdneri). Water Res., 19, 209-214.

(103) BILLARD R., 1978. Effets des alcools gras sur la fécondation et les gamètes de la truite arc-en-ciel. Bull. fr. Pisci., 271, 3-8. 
(104) BILLARD R., de KINKELIN P., 1970. Stérilisation des testicules de Guppies par des doses non léthales de parathion. Ann. Hydrobiol., 1, 91-99.

(105) BILLARD R., 1980. Prolongation de la durée de motilité et du pouvoir fécondant des spermatozoïdes de truite arc-en-ciel par addition de théophylline au milieu de dilution. C. R. Acad. Sci., Paris, 291, 649-652.

\section{II. - Other references}

ABRAHAM M., RAHAMIM E., TIBIKA H., GOLENSER E., KIESELSTEIN M., 1980. The bloodtestis barrier in Aphanius dispar (Teleostei). Cell Tissue Res., 211, 207-214.

BARNABE G., 1976. Contribution à la connaissance de la biologie du loup Dicentrarchus labrax (Poissons Serranidae). Th. Doct. Etat. Sci. nat., Univ. Sci. Tech. du Languedoc.

BENAU D., TERNER C., 1980. Initiation, prolongation and reactivation of salmonid spermatozoa. Gamete Res., 3, 247-257.

BERGMANN M., SCHINDELMEISER J., GREVEN H., 1984. The blood-testis barrier in vertebrates having different testicular organization. Cell Tissue Res., 238, 145-150.

BILLARD R., 1966. Contribution à l'étude de la reproduction chez le poisson téléostéen Lebistes reticulatus, au moyen de l'insémination artificielle. Th. $3^{\ominus}$ Cycle, Fac. Sci. Lyon.

BILLARD R., BRETON B., 1978. Rhythms of reproduction in teleost fish, 31-53. In J. E. THORPE, Rhythmic activity of fishes, Acad. Press.

BOISSEAU J., 1967. Les régulations hormonales de l'incubation chez un Vertébré mâle : recherches sur la reproduction de l'Hippocampe. Th. Doct. Etat. Sci. Nat., Fac. Sci. Bordeaux.

BREDER C. M., ROSEN D. E., 1966. Modes of reproduction in fishes. Am. Mus. Nat. Hist. Publ., New York.

BRETON B., JALABERT B., REINAUD P., 1976. Purification of gonadotropin from rainbow trout (Salmo gairdneri Richardson). Pituitary glands. Ann. Biol. anim. Bioch. Biophys., 16, 25-36.

BROCK J., 1878. Beitrage zur Anatomie und Histologie der Geschtolchtsorgane der Knockenfische. Morphol. Jahr., 4, 505-572.

BRUSLÉ S., 1982. Contribution à la connaissance de la sexualité de poissons téléostéens marins gonochoriques (Mugilidés) et hermaphrodites (Serranidés). Th. Doct. Sci. Nat., Univ. Perpignan.

BURZAWA-GÉRARD E., 1973. Etude biologique et biochimique de l'hormone gonadotrope d'un poisson téléostéen, la Carpe (Cyprinus carpio L. I. Th. Doct. Sci. Nat., Univ. Paris VI.

CHRISTEN R., SCHACKMANN R. W., SHAPIRO B. M., 1982. Elevation of the intracellular $\mathrm{pH}$ activates respiration and motility of sperm of the sea urchin, Strongylocentrotus purpuratus. J. biol. Chem., 257, 14881-14890.

COLOMBO L., BELVEDERE P. C., MARCONATO A., BENTIVEGNA F., 1982. Pheromones in teleost fish, 84. In Reproductive physiology of fish, C. J. J. RICHTER and H. J. Th. GOOS. PUDOC Wageningen.

CRAIG-BENNETT A., 1931. The reproductive cycle of the three-spined stickleback, Gasterosteus aculaetus L. Phil. Trans. roy Soc. Lond., B 219, 197-279.

CREWS D., 1984. Gamete production, sex hormone secretion, and mating behavior uncoupled. Hormones and behavior, 18, 22-28.

DAVIS J. R., LANGFORD G. A., KIRBY P. J., 1970. The testicular capsule, 282-334. In A. D. JOHNSON, W. R. GOMES and N. L. VANDEMARD, The testis, Acad. Press. New York, London.

DEMSKI D. J., HORNBY P. J., 1982. Hormonal control of fish reproductive behavior: braingonadal steroid interactions. Can. J. Fish. Aauat. Sci., 39, 36-47.

DEROCHE S. E., 1969. Observations on the spawning habits and early life of lake trout. Progr. Fish Cult., 31, 109-113.

DRAGOTOIU C., 1963. Contributions à l'étude des organes reproducteurs mâles de Cyprinus carpio L. Trav. Mus. Hist. nat., Bucarest, 4, 325-338.

DUSHKINA L. A., 1973. Influence of salinity on eggs, sperm and larvae of low-vertebrates herring reproducing in the coastal water of the Soviet Union. Marine Biol., 19, 210-223. 
DYM M., FAWCETT D. W., 1971. Further observations on the numbers of spermatogonia, spermatocytes, and spermatids connected by intercellular bridges in the mammalian testis. Biol. Reprod., 4, 195-215.

FELICE De D. A., RASCH E. M., 1969. Chronology of spermatogenesis and spermiogenesis in Poeciliid fishes. J. exp. Zool., 171, 191-207.

FONTAINE Y. A., 1984. Les hormones et l'évolution. La Recherche, 153, 311-320.

FOSTIER A., JALABERT B., BILLARD R., BRETON B., ZOHAR Y., 1983. The gonadal steroids, 277-312. In Fish physiology, W. S. HOAR, D. J. RANDALL and E. M. DONALDSON Eds. Acad. Press, New York, London (vol. IXA).

GARDINER D. M., 1978a. Fine structure of the spermatozoon of the viviparous teleost, Cymatogaster aggregata. J. Fish Biol., 13, 435-438.

GARDINER D. M., 1978b. The origin and fate of spermatophores in the viviparous Teleost Cymatogaster aggregata (Perciformes: Embiotocidae). J. Morphol., 155, 157-171.

GRESIK E. W., 1975. Homologs of Leydig and Sertoli cells in the testis of the teleost Oryzias latipes, 231-242. In Electron microscopic concepts of secretion, Hess and J. Wiley Eds.

GRESIK E. W., QUIRK J. G., HAMILTON J. B., 1973. Fine structure of the Sertoli cell of the testis of the teleost Oryzias latipes. Gen. comp. Endocrinol., 21, 341-352.

GRIER H. J., 1976. Sperm development in the teleost Oryzias latipes. Cell Tissue Res., 168. 419-431.

GRIER H. J., 1981. Cellular organization of the testis and spermatogenesis in fishes. Am. Zool., 21, 345-357.

GRIER H. J., FITZSIMONS J. M., LINTON J. R., 1978. Structure and ultrastructure of the testis and sperm formation in goodeid teleosts. $J$. Morphol, 156, 419-438.

GRIER H. J., LINTON J. R., LEATHERLAND J. F., De VLAMING V. L., 1980. Structural evidence for two different testicular types in teleost fishes. Am. J. Anat., 159, 331-345.

GRIER H. J., BURNS J. R., FLORES J. A., 1981. Testis structure in three species of teleosts with tubular gonopodia. Copeia, (4), 797-801.

GROSS M. R., 1984. Sunfish, salmon, and the evolution of alternative reproductive strategies and tactics in fishes. $50 \mathrm{p}$. in Fish reproduction. Strategies and tactics, R. J. WOOTON and G. POTTS Eds., Acad. Press.

GUYOMARC'H J. P., 1970. La spermatogenèse chez Nerophis lumbricitormis (Téléostéen Syngnathidés). Th. 3e Cycle, Fac. Sci. Brest. $92 \mathrm{pp.}$

HARCOURT A. H., HARVEY P. H., LARSON S. G., SHORT R. V., 1981. Testis weight, body weight and breeding system in primates. Nature, 293, 55-57.

HARVEY P. H., HARCOURT A. H., 1982. Sperm competition, testes size and breeding systems in primates. In R. L. SMITH, Sperm competition and the evolution of animal mating systems. Acad. Press.

HAYASHI I., 1969. Some observations on the reproductive duct of the japanese sea bass, Lateolabrax japonicus (Cuvier and Valenciennes). Jap. J. Ichthyol., 16, 68-76.

HENDERSON N. E., 1962. The annual cycle in the testis of eastern brook trout Salvelinus fontinalis (Mitchill). Can. J. Zool., 40, 631-641.

HIROI O., YAMAMOTO K., 1968. Studies on the maturation of salmonid fishes. I. Changes in the testis of the chum salmon Oncorhynchus keta, during anadromous migration. Bull. Fac. Fish Hokkaido Univ., 19, 173-184.

HIROI O., YAMAMOTO K., 1970. Studies on the maturation of salmonid fishes. II. Changes in the testis of the masu salmon, Oncorhynchus masou, during andromous migration. Bull. Fac. Fish Hokkaido Univ., 20, 252-264.

HURK Van Den R., LAMBERT J. G. D., 1983. Ovarian steroid glucuronides function as sex pheromones for male zebrafish, Brachydanio rerio. Can. J. Zool., 61, 2381-2387.

HURK Van Den R., MEEK J., PEUTE J., 1974. Ultrastructural study of the testis of the black molly (Mollienisia latipinna). II. Sertoli cells and Leydig cells. Koninkl. Nederi. Akad. Wetenschappen-Amsterdam, Ser. C, 77, 470-476.

HURK Van Den R., PEUTE J., VERMEIJ J. A. J., 1978. Morphological and enzyme cytochemical aspects of the testis and vas deferens of the rainbow trout Salmo gairdneri. Cell Tissue Res., 186, 309-325. 
HURK Van Den R., LAMBERT J. G. D., PEUTE J., 1982. Steroidogenesis in the gonads of rainbow trout fry (Salmo gairdneri) before and after the onset of gonadal sex differentiation. Reprod. Nutr. Dévelop., 22, 413-425.

HYDER M., 1970. Gonadal and reproductive pattern in Tilapia leucosticta (Teleostei : Cichlidés). J. Zool., 162, 179-195.

IDLER D. R., NG T. B., 1983. Teleost gonadotropins : isolation, biochemistry and function, 187-221. In Fish physiology (vol. IXA), W. S. HOAR, D. J. RANDALL and E. M. DONALDSON Eds., Acad. Press, New York, London.

JONAS-DAVIES J. A. C., WINFREY V., OLSON G. E., 1983. Plasma membrane structure in spermatogenic cells of the swordtail (Teleostei, Xiphophorus helleri). Gamete Res., 4, 309-324.

JONES J. W., ORTON J. H., 1940. The paedogenetic male cycle in Salmo salar L. Proc. roy. Soc., London, 128, 485-498.

KHAN I. A., 1983. Contróle hormonal du fonctionnement testiculaire chez un poisson téléosteen (Anguilla anguilla L.) ; structure histologique, morphologique et androgènes plasmatiques. Th. $3^{e}$ Cycle, Univ. Paris VI.

KIME D. E., 1979. The effect of temperature on the steroidogenic enzyme of the rainbow trout. Gen. comp. Endocrinol., 35, 322-328.

LAIRD L. M., ELLIS A. E., WILSON A. R., HOLLIDAY F. G. T., 1978. The development of the gonadal and immune systems in the atlantic salmon (Salmo salar L.) and a consideration of the possibility of inducing autoimmune destruction of the testis. Ann. Biol. anim. Bioch. Biophys., 18, 1101-1106.

LAM T. J., 1983. Environmental influences on gonadal activity in fish, 65-116. In Fish physiology, Vol. IX, W. S. HOAR, D. J. RANDALL and E. M. DONALDSON Eds., Acad. Press, New York, London.

LOFTS B., MARSHALL A. J., 1957. Cyclical changes in the distribution of the testis lipids of a teleost fish, Esox lucius. Quart. J. micr. Sci, 98, 79-98.

MAGRI M. H., 1983. Action facilitante de l'hormone gonadotrope ou de stéroïdes sexuels sur le déclenchement de la puberté chez la truite arc-en-ciel. Interférence avec la photopériode. Th. $3^{e}$ Cycle, Univ. Paris VI.

MARCAILLOU C., SZÖLLÖSI A., 1980. The "Blood-testis " barrier in a nematode and a fish : a generalizable concept. J. U/trast. Res., 70, 128-136.

MATTEI X., MATTEI C., MARCHAND B., LEUNG TACK KIT D., 1982. Ultrastructure des celluies de sertoli d'un poisson téléostéen : Abudefduf marginatus. J. Uitrast. Res., 81, 333-340.

MEDFORD B. A., MACKAY W. C., 1978. Protein and lipid content of gonad, liver and muscle of northern pike (Esox /ucius) in relation to gonad growth. J. Fish Res. Board Can., 35, 213-219.

MICHIBATA H., 1975. Cell population kinetics of primary spermatogonia activated by warm temperatures in the teleost, Oryzias latipes during the winter months. J. Fac. Sci. Univ. Tokyo, Sec. 4, 13, 299-309.

NAGAHAMA Y., 1983. The functional morpholngy of teleost gonads, 223-265. In Fish physiology, vol. IXA, W. S. HOAR, D. J. RANDALL and E. M. DONALDSON Eds. Acad. Press, New York, London.

NAGAHAMA Y., CLARKE W. C., HOAR W. S., 1978. Ultrastructure of putative steroid-producing cells in the gonads of coho (Oncorhynchus kisutch) and pink salmon (Oncorhynchus gorbuschal. Can. J. Zool., 56, 2508-2519.

PAPADOPOL M., 1962. Nouvelles données concernant la biologie de la reproduction de la brème (Abramis brama L.) du cours inférieur du Danube (en roumain). Studii. Cercet. Biol., Ser. Biol. anim., 14, 393-400.

PAYNE A. I., 1975. The reproductive cycle, condition and feeding in Barbus liberiensis, a tropical stream-dwelling cyprinid. J. Zool., 176, 247-269.

PETERS H. M., 1971. Testis weights in Tilapia (Pisces : Cichlidae). Copeia (1), 13-17.

PETIT J., 1974. Recyclage et épuration en pisciculture : étude théorique et bibliographique. Coll. Aquac., CNEXO Brest, 445-470.

PHILIPPI E., 1908. Spermatophoren bei Fischen. Verh. d. deutsch Zool. Gesellsch., 17. 105-108.

ROOSEN-RUNGE E. C., 1977. The process of spermatogenesis in anima/s. Cambridge Univ. Press, Cambridge, London, New York, Melbourne. 
ROSENTHAL H. L., 1952. Observations on reproduction of the poeciliid Lebistes. Biol. Bull., 102, 30-38.

RUBY S. M., MCMILLAN D. B., 1975. The interstitial origin of germinal cells in the testis of the stickleback. J. Morphol., 145, 295-317.

SANCHEZ-RODRIGUEZ M., ESCAFFRE A.-M., MARLOT S., REINAUD P., 1978. The spermiation period in the rainbow trout (Salmo gairdneri). Plasma gonadotropin and androgen levels, sperm production and biochemical changes in the seminal fluid. Ann. Biol. anim. Bioch. Biophys., 18, 943-948.

SCOTT A. P., BAYNES S. M., 1982. Plasma levels of sex steroids in relation to ovulation and spermiation in rainbow trout (Salmo gairdneri), 103-106. In Reproductive physiology of fish, C. J. J. RICHTER and H. J. Th. GOOS. PUDOC, Wageningen.

SCOTT D. B. C., FULLER J. O., 1976. The reproductive biology of Scleropages formosus (Mullet \& Schlegel) (Osteoglossomorpha osteog/ossidae) in Malaya and the morphology of its pituitary gland. J. Fish. Biol., 8, 45-53.

SOLEWSKI W., 1957. Rozwoj gruczolow plciowych u karpia (Cyprinus carpio L.) w ciagu pierwszych trzech lat zycia. Biul. Zaktadu Biol. Stavev Polskiy Akad. Nauk Krakov, 24-30, 3-24.

STOSS J., 1983. Fish gamete preservation and spermatozoan physiology, 305-350. In HOAR W. S., RANDALL D. J., DONALDSON E. M., Fish physiology, vol. IX. Acad. Press, New York, London.

TAKAHASHI H., TAKANO K., 1972. Morphogenesis of accessory reproductive organs in male goldfish, Carassius auratus. Bull. Fac. Fish. Hokkaido Univ., 23, 53-64.

TAKASHIMA F., PATINO R., NOMURA M., 1980. Histological studies on the sex differentiation in rainbow trout. Bull. jap. Soc. Sci. Fish, 46, 1317-1322.

THIENOVEN B. Van, 1983. Reproductive physiology in vertebrates (2nd Edition). WB Saunders, Philadelphia, London, Toronto.

TURDAKOV A. F., 1968. Production of sperm by the males of Issyk Kuli trout. Vopr. /cht., 8, 253-265.

WIEBE J. P., 1968. The effects of temperature and daylength on the reproductive physiology of the viviparous seaperch, Cymatogaster aggregata Gibbons. Can. J. Zool., 46, 1207-1219.

WEIL C., 1981. La fonction gonadotrope de l'hypophyse au cours du cycle sexuel chez deux poissons téléostéens: la carpe commune (Cyprinus carpio), et la truite arc-en-ciel (Salmo gairdneri), son contrôle par l'hypothalamus, les gonades et les facteurs externes. Th. Doc. Etat, Univ. Paris VI.

WEIL C., CRIM L. W., 1983. Administration of LHRH analogues in various ways: effect on the advancement of spermiation in prespawning Landlocked salmon Salmo salar. Aquaculture, 35, 103-115.

WIART P., 1936. Variations saisonnières du testicule des téléostéens. Trav. Stat. Biot. Roscoff, 14-16, 79-86.

ZOHAR Y., 1982. La dynamique nycthémérale de la sécrétion gonadotrope chez la truite arc-en-ciel femelle au cours du cycle annuel : analyse descriptive et analyse expérimentale de sa fonction dans la régulation ovarienne. Th. Doc. Etat, Univ. Paris VI. 